\title{
Numerical Simulation of the Burning Process in a King-Size Cigarette Based on Experimentally Derived Reaction Kinetics *
}

by

Qiaoling Li ${ }^{1}$, Quanxing Zheng ${ }^{1}$, Xiaohua Deng ${ }^{1}$, Zhiqiang Yu ${ }^{1}$, Nan Deng ${ }^{2}$, Fei Xing ${ }^{3}$, Xin Chen ${ }^{1}$, Guohua Cai ${ }^{l}$, Chenlu Wang ${ }^{3}$, Renqiang Yang ${ }^{1}$, Pengfei $\mathrm{Ma}^{1}$, Bin Li ${ }^{2}$, Xiao Dong Chen ${ }^{4}$, and Hongxiang Zhong ${ }^{l}$

Technology Center, China Tobacco Fujian Industrial Co., Ltd., Xiamen 361021, Fujian, P.R. China

Key Laboratory of Tobacco Processing Technology of CNTC, Zhengzhou Tobacco Research Institute of CNTC, Zhengzhou 450001, P.R. China

3 School of Aerospace Engineering, Xiamen University, Xiamen, Fujian, 361102, P.R. China

4 School of Chemical and Environmental Engineering, College of Chemistry, Chemical Engineering and Materials Science, Soochow University, Suzhou, 215123, P.R. China

\section{SUMMARY}

A comprehensive two-dimensional (2D) mathematical model has been proposed to simulate the burning process of a king-size cigarette. The characteristics of this model are including: 1) the use of kinetic models for the evaporation of water, the pyrolysis of tobacco and the oxidation of char, 2) the application of mathematical relationships between the release amounts of certain products (i.e., "tar" and $\mathrm{CO}$ ) and different reaction variables (i.e., temperatures and oxygen concentrations), 3) the introduction of mass, heat and momentum transports, 4) the consideration of filtration effects of the cigarette filter on "tar". These characteristics were expressed in a set of coupled equations that can be solved numerically by FLUENT. The information about the char density field, temperature field, flow velocity field, "tar" and CO density fields and the filtration efficiency could be obtained from the model. This model was validated by comparing the predictions with experimental data on puff number, the temperatures at specific locations, the filtration efficiency and the yields of "tar" and $\mathrm{CO}$ under different puff intensities. The calculated results show a good agreement with the experimental data. The predicted puff number was 7.3 , and the experimental puff number was 6.8. The standard root mean square error (NRMSE) between the experimental and the predicted temperatures at specific locations is $<18 \%$. The predicted filtration efficiency for "tar" was $46.1 \%$, and the experimentally determined filtration efficiency for nicotine was $44.5 \%$. The maximum relative deviations of the yields of "tar" and CO under different puff intensities were $8.9 \%$ and $10.6 \%$, respectively. [Beitr. Tabakforsch. Int. 29 (2020) $156-179]$

\section{KEY WORDS:}

Numerical simulation; cigarette burning process; pyrolysis; combustion; "tar" and CO release; filtration efficiency

\section{ZUSAMMENFASSUNG}

Es wurde ein umfassendes zweidimensionales (2D) mathematisches Modell zur Simulation des Verbrennungsprozesses in einer King-Size-Zigarette vorgeschlagen. Die Eigenschaften dieses Modells umfassten: 1) die Verwendung von kinetischen Modellen für die Verdampfung des Wassers,

*Received: $10^{\text {th }}$ April 2020 - accepted: $22^{\text {nd }}$ December 2020 
die Pyrolyse des Tabaks und die Oxidation der Kohle, 2) die Anwendung mathematischer Beziehungen zwischen den Freisetzungsmengen bestimmter Produkte (z.B. "Teer" und $\mathrm{CO}$ ) und verschiedenen Reaktionsvariablen (z.B. Temperaturen und Sauerstoffkonzentrationen), 3) die Einführung von Masse-, Wärme- und Impulstransport, 4) die Berücksichtigung von Filtrationseffekten des Zigarettenfilters in Bezug auf "Teer". Diese Eigenschaften wurden in einem System gekoppelter Gleichungen ausgedrückt, die numerisch mit FLUENT gelöst werden können. Mithilfe des Modells konnten Informationen zur Dichte der Kohle, dem Temperaturfeld, dem Strömungsgeschwindigkeitsfeld, den Dichtefeldern von "Teer" und CO und der Filtrationseffizienz ermittelt werden. Die Validierung des Modells erfolgte durch einen Vergleich der Prognosen mit den experimentellen Daten zur Zugzahl, den Temperaturen an spezifischen Punkten, der Filtrationseffizienz und den Ausbeuten an "Teer" und CO bei unterschiedlichen Zugintensitäten. Die berechneten Ergebnisse zeigten eine gute Übereinstimmung mit den Versuchsdaten.

Die prognostizierte Zugzahl lag bei 7,3 - diejenige im Experiment bei 6,8. Der normalisierte mittlere quadratische Fehler (NRMSE) zwischen den experimentellen und prognostizierten Temperaturen an spezifischen Punkten betrug $<18 \%$. Die prognostizierte Filtrationseffizienz für "Teer" lag bei $46,1 \%$, die im Versuch bestimmte Filtrationseffizienz für Nikotin lag bei 44,5\%. Die maximale relative Abweichung der Ausbeuten an "Teer" und CO bei unterschiedlichen Zugintensitäten betrug jeweils 8,9\% und 10,6\%. [Beitr. Tabakforsch. Int. 29 (2020) 156-179]

\section{RESUME}

Un modèle mathématique bidimensionnel (2D) complet fut proposé en vue de simuler le processus de combustion d'une cigarette king size. Les caractéristiques de ce modèle inclurent 1) l'utilisation de modèles cinétiques pour l'évaporation de l'eau , la pyrolyse du tabac et l'oxydation du résidu carbonisé, 2) l'application de relations mathématiques entre les quantités libérées de certains produits (par ex. le goudron et le $\mathrm{CO}$ ) et diverses variables de réaction (par ex. les températures et les concentrations en oxygène), 3) l'introduction des transferts de quantité de mouvement, de chaleur et de masse et 4) la prise en compte des effets filtrants du filtre de la cigarette sur le goudron. Ces caractéristiques furent traduites en un ensemble d'équations couplées susceptibles d'être résolues numériquement sous FLUENT. Les informations relatives au champ de densité du résidu carbonisé, au champ de température, au champ de vitesse d'écoulement, aux champs de densité du CO et du goudron et à l'efficacité du filtre purent être déterminées à partir du modèle. Ce modèle fut validé par comparaison des prédictions et des données expérimentales relatives au nombre de bouffées, aux températures en des points précis et aux rendements de goudron et de $\mathrm{CO}$ à diverses intensités de bouffée. Les résultats calculés révélèrent une bonne concordance avec les données expérimentales. Le nombre prédit de bouffées s'éleva à 7,3 alors que le nombre expérimental de bouffées fut de 6,8. L'erreur quadratique moyenne normalisée $(\mathrm{EQMN})$ entre les températures prédites et expérimentales en des points spécifiques fut de
$<18 \%$. L'efficacité de filtration prédite pour le goudron atteignit $46,1 \%$ et l'efficacité de filtration déterminée par expérimentation pour la nicotine fut de $44,5 \%$. Les écarts relatifs maximaux sur les rendements du goudron et du $\mathrm{CO}$ à diverses intensités de bouffée s'élevèrent respectivement à $8,9 \%$ et $10,6 \%$. [Beitr. Tabakforsch. Int. 29 (2020) 156-179]

\section{INTRODUCTION}

The modeling of the cigarette smoking process is a challenge because it involves complex chemical reactions, interactions of many thermo-physical processes, such as heat, mass and momentum transfer, and the filtration mechanism of the filter for aerosols. However, establishing a mathematical model of cigarette combustion and the indepth analysis of the smoking process are important for the design of cigarettes.

Since EGERTON et al. (1) first tried to model the burning process of a cigarette, several mathematical models have been established in the last fifty years, as shown in Table 1 (2-18). Obviously, the modeling work has made significant progress. It is worth noting that during the first few decades almost all models published were restricted to a burning cigarette under free convection or steady draw conditions. In 2004 SAIDI et al. (14) developed a three-dimensional model to simulate a burning cigarette during puffing. Afterwards more comprehensive models were reported, which could simulate the puff-smoldering cycles of a lit cigarette and provide more information about the cigarette burning behavior $(17,18)$.

During the numerical simulation of a burning cigarette, the establishment of a tobacco pyrolysis and combustion kinetics model is a key step. The kinetics will determine the amount of tobacco involved in the reactions and the yield of char. At the same time, the heat released by char oxidation is transferred back to the tobacco, which forms a selfsustaining burning cycle of the cigarette. Finally, the reaction kinetics will affect the temperature and oxygen distribution, burning rate and smoke composition.

Table 1 shows that most literature published after 2003 applied the kinetics of pyrolysis and char oxidation reactions proposed by MURAMATSU et al. $(5,6)$ and WOJTOWICZ et al. (15), who carried out their thermogravimetry (TG) analysis experiments at heating rates between $10 \mathrm{~K} \cdot \mathrm{min}^{-1}$ and $100 \mathrm{~K} \cdot \mathrm{min}^{-1}$. This heating rate was much lower than what is actually present in a cigarette during smoldering and puffing. "Tar" and CO are two important factors for cigarette design. In Table 1, we also found that only SAIDI et al. $(14,17,18)$ predicted the yields of $\mathrm{CO}$ in their model by using TG-FTIR data reported by WoJTOWICZ et al. (15). To the best of our knowledge, no one has yet predicted the yields of "tar" in the mathematical model of the cigarette burning process.

Therefore, in this work, we set up the kinetics of pyrolysis and char oxidation reactions by extending the heating rate to $800 \mathrm{~K} \cdot \mathrm{min}^{-1}$ and the oxygen-mass fraction ranging from $1 \%$ to $20 \%$, respectively. The mathematical relationships of "tar" and CO at different temperatures and oxygen concentrations were obtained by a specifically designed tobacco pyrolysis and combustion experimental platform, in which 
Table 1. The mathematical models of cigarette reported in the literatures.

\begin{tabular}{|c|c|c|c|c|c|c|c|}
\hline \multirow[b]{2}{*}{$\begin{array}{l}\text { Reference } \\
\text { and year }\end{array}$} & \multirow[b]{2}{*}{ Author(s) } & \multirow[b]{2}{*}{$\begin{array}{l}\text { Smoking } \\
\text { conditions }\end{array}$} & \multirow[b]{2}{*}{ Geometry } & \multicolumn{2}{|c|}{ Model construction } & \multicolumn{2}{|c|}{ Simulation contents } \\
\hline & & & & $\begin{array}{l}\text { Pyrolysis and char } \\
\text { oxidation reaction } \\
\text { kinetics }\end{array}$ & $\begin{array}{l}\text { Transport } \\
\text { system }\end{array}$ & Burning properties & Products \\
\hline $\begin{array}{l}(1) \\
1963\end{array}$ & $\begin{array}{l}\text { EGERTON } \\
\text { et al. }\end{array}$ & Steady draw & $1-D$ & - & $\sqrt{ }$ & Temperature & - \\
\hline $\begin{array}{l}(2) \\
1966\end{array}$ & GuGAN & Smoldering & $2-D$ & - & $\sqrt{ }$ & $\begin{array}{l}\text { Combustion cone } \\
\text { Temperature }\end{array}$ & - \\
\hline $\begin{array}{l}(3) \\
1977\end{array}$ & BAKER & Smoldering & $1-D$ & - & $\sqrt{ }$ & $\begin{array}{l}\text { Heat release rate } \\
\mathrm{O}_{2} \text { concentration }\end{array}$ & $\mathrm{CO}, \mathrm{CO}_{2}$ \\
\hline $\begin{array}{l}(4) \\
1978\end{array}$ & $\begin{array}{l}\text { SUMMERFIELD } \\
\text { et al. }\end{array}$ & Steady draw & $1-D$ & $\begin{array}{l}\text { Using the kinetics } \\
\text { parameters obtained } \\
\text { by themselves (4) }\end{array}$ & $\sqrt{ }$ & $\begin{array}{l}\text { Burning rate } \\
\text { Temperature } \\
\text { Pressure }\end{array}$ & - \\
\hline $\begin{array}{l}(5-7) \\
1979-1981\end{array}$ & $\begin{array}{l}\text { MURAMATSU } \\
\text { et al. }\end{array}$ & Smoldering & $1-D$ & $\begin{array}{l}\text { Using the kinetics } \\
\text { parameters obtained } \\
\text { by themselves }(5,6)\end{array}$ & $\sqrt{ }$ & $\begin{array}{l}\text { Burn rate } \\
\text { Temperature } \\
\text { Density }\end{array}$ & - \\
\hline $\begin{array}{l}(8) \\
2001\end{array}$ & $\begin{array}{l}\text { MIURA } \\
\text { et al. }\end{array}$ & Smoldering & $1-D$ & - & $\sqrt{ }$ & $\begin{array}{l}\text { Burning rate } \\
\text { Temperature }\end{array}$ & - \\
\hline $\begin{array}{l}(9) \\
2001\end{array}$ & $\begin{array}{l}\text { Yl } \\
\text { et al. }\end{array}$ & Smoldering & $2-D$ & $\begin{array}{l}\text { Using the kinetics } \\
\text { parameters obtained } \\
\text { by DIBLASI }(10)\end{array}$ & $\sqrt{ }$ & $\begin{array}{l}\text { Temperature } \\
\text { Solid density } \\
\text { Char density } \\
\mathrm{O}_{2} \text { concentration }\end{array}$ & Water \\
\hline $\begin{array}{l}(11) \\
2002\end{array}$ & CHEN & Smoldering & $1-D$ & $\begin{array}{l}\text { Using the kinetics } \\
\text { parameters obtained } \\
\text { by themselves (11) }\end{array}$ & $\sqrt{ }$ & $\begin{array}{l}\text { Temperature } \\
\text { Density }\end{array}$ & - \\
\hline $\begin{array}{l}(12) \\
2003\end{array}$ & $\begin{array}{l}\text { RostAMI } \\
\text { et al. }\end{array}$ & Smoldering & $2-D$ & $\begin{array}{l}\text { Using the kinetics } \\
\text { parameters reported by } \\
\text { MURAMATSU et al. }(5,6)\end{array}$ & $\sqrt{ }$ & $\begin{array}{l}\text { Burning rate } \\
\text { Temperature } \\
\mathrm{O}_{2} \text { concentration }\end{array}$ & - \\
\hline $\begin{array}{l}(13) \\
2004\end{array}$ & $\begin{array}{l}\text { RostAMI } \\
\text { et al. }\end{array}$ & $\begin{array}{l}\text { Smoldering and } \\
\text { steady draw }\end{array}$ & $2-D$ & $\begin{array}{l}\text { Using the kinetics } \\
\text { parameters reported by } \\
\text { MURAMATSU et al. }(5,6)\end{array}$ & $\sqrt{ }$ & $\begin{array}{l}\text { Temperature } \\
\mathrm{O}_{2} \text { concentration } \\
\text { Pressure } \\
\text { Flow velocity }\end{array}$ & - \\
\hline $\begin{array}{l}(14) \\
2004\end{array}$ & SAIDI et al. & Puffing & $3-D$ & $\begin{array}{l}\text { Using the kinetics } \\
\text { parameters for volatile } \\
\text { species reported by } \\
\text { WoJTOWICZ et al. (15) }\end{array}$ & $\sqrt{ }$ & $\begin{array}{l}\text { Burning rate } \\
\text { Temperature } \\
\text { Flow velocity } \\
\mathrm{O}_{2} \text { concentration }\end{array}$ & $\begin{array}{l}\mathrm{CO}, \mathrm{CO}_{2} \\
\mathrm{H}_{2} \mathrm{O} \\
\text { Nicotine }\end{array}$ \\
\hline $\begin{array}{l}(16) \\
2005\end{array}$ & $\begin{array}{l}\text { EITZINGER } \\
\text { et al. }\end{array}$ & $\begin{array}{l}\text { Smoldering, puffing } \\
\text { and steady draw }\end{array}$ & $2-D$ & $\begin{array}{l}\text { Using the kinetics } \\
\text { parameters obtained } \\
\text { by themselves (16) }\end{array}$ & $\sqrt{ }$ & $\begin{array}{l}\text { Burning rate } \\
\text { Temperature } \\
\text { Flow velocity } \\
\mathrm{O}_{2} \text { concentration }\end{array}$ & $\begin{array}{l}\text { Combustion } \\
\text { gas } \\
\text { Water }\end{array}$ \\
\hline $\begin{array}{l}(17) \\
2007\end{array}$ & SAIDI et al. & $\begin{array}{l}\text { Puff-smoldering } \\
\text { cycles }\end{array}$ & $3-D$ & $\begin{array}{l}\text { Using the kinetics } \\
\text { parameters for volatile } \\
\text { species reported by } \\
\text { WoJTOWICZ et al. (15) }\end{array}$ & $\sqrt{ }$ & $\begin{array}{l}\text { Burning rate } \\
\text { Temperature } \\
\text { Flow velocity } \\
\mathrm{O}_{2} \text { concentration } \\
\text { Char density }\end{array}$ & $\begin{array}{l}\mathrm{CO}, \mathrm{CO}_{2} \\
\text { Volatile }\end{array}$ \\
\hline $\begin{array}{l}(18) \\
2008\end{array}$ & SAIDI et al. & $\begin{array}{l}\text { Puff-smoldering } \\
\text { cycles }\end{array}$ & $3-D$ & $\begin{array}{l}\text { Using the kinetics } \\
\text { parameters for volatile } \\
\text { species reported by } \\
\text { WoJToWICz et al. (15) }\end{array}$ & $\sqrt{ }$ & $\begin{array}{l}\text { Burning rate } \\
\text { Temperature } \\
\text { Flow velocity } \\
\text { Char density }\end{array}$ & $\begin{array}{l}\mathrm{CO}, \mathrm{CO}_{2} \\
\mathrm{H}_{2} \mathrm{O}\end{array}$ \\
\hline
\end{tabular}

the tobacco loading was $1 \mathrm{~g}$ compared to the TG experiment with a loading of $\mathrm{mg}$. Thus, the experimental platform ensured that the release of "tar" and CO met the requirements of detection, and achieved data repeatability and accuracy. Furthermore, in order to predict the yields of "tar", we applied the filtration mechanism model of aerosols in filters proposed by Du et al. (19) into the cigarette burning model. In the subsequent sections, the model is described, followed by a description of the governing equations and the boundary conditions.

Based on other contributions related to understanding and treatment of the cigarette burning process, this study aims to establish a relatively comprehensive model for prediction of the cigarette burning behavior and the yields of "tar" and
$\mathrm{CO}$, which includes the complex reactions, transport system, and the filtration effect of cigarette filter for "tar". Finally, the computed results will be compared with experimental data.

\section{MATERIALS AND METHODS}

\subsection{Material}

The cigarette samples were obtained from China Tobacco Fujian Industrial Corporation (Xiamen, Fujian, P.R. China). For $48 \mathrm{~h}$ prior to analysis, the samples were conditioned in a chamber at $295 \mathrm{~K}$ and relative humidity of $60 \%$. 


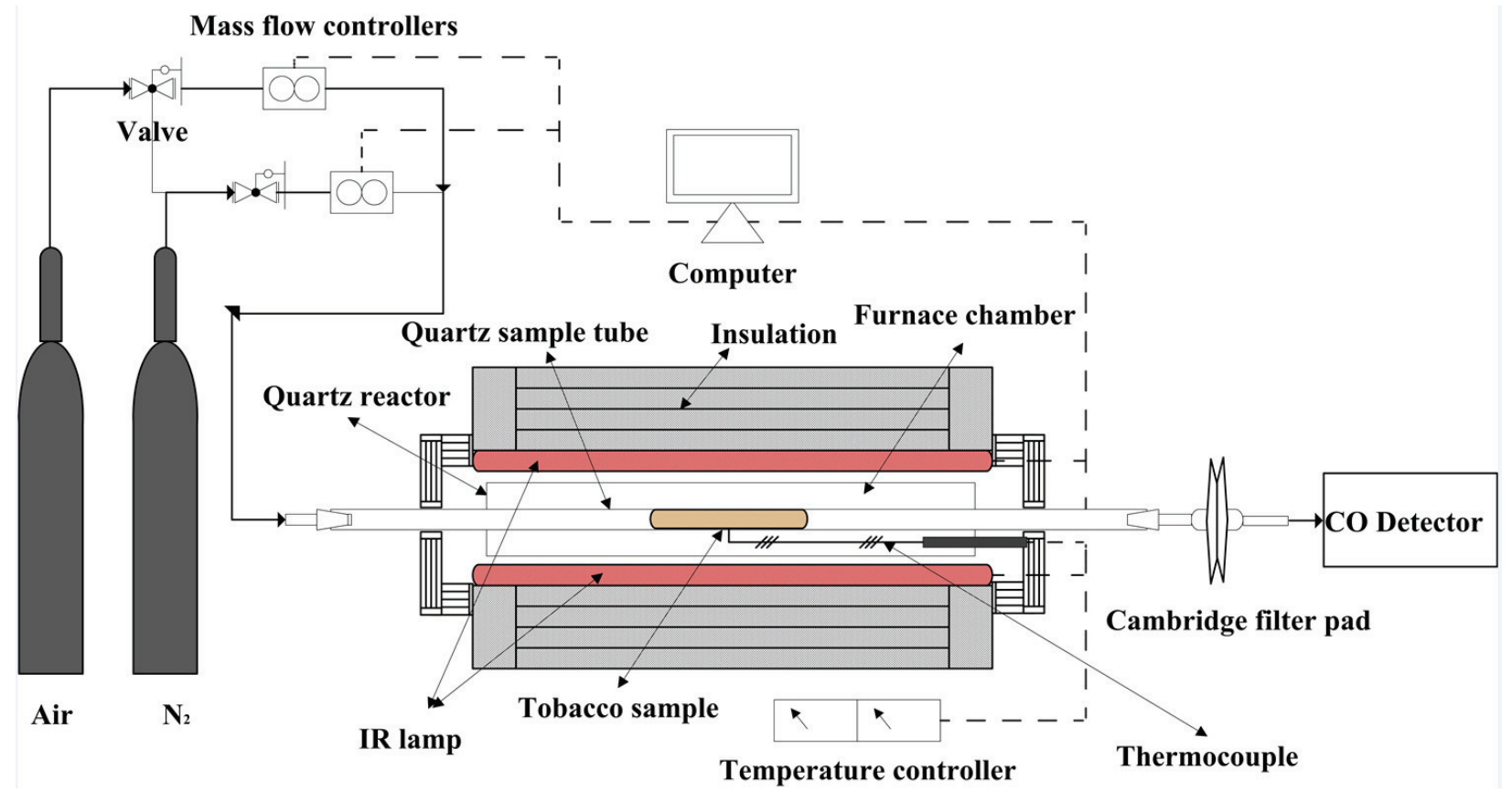

Figure 1. Schematic diagram of tobacco pyrolysis and combustion reaction system.

\subsection{Thermogravimetric experiment}

The cut tobacco from the cigarette sample was pulverized into powder and then sifted through a 100-mesh sieve. $10 \mathrm{mg}$ of tobacco powder were loaded evenly into an open ceramic pan. The pan was then placed on the sample holder of a SAT 449 F3 (Netzsch Feinmahltechnik GmbH, Selb, Germany). In the first stage, the tobacco powder was pyrolyzed under nitrogen atmosphere. The temperature was increased from room temperature to $873 \mathrm{~K}$ in pure nitrogen with a steady flow rate of $100 \mathrm{~mL} \cdot \mathrm{min}^{-1}$. The heating rates were $300 \mathrm{~K} \cdot \mathrm{min}^{-1}, 400 \mathrm{~K} \cdot \mathrm{min}^{-1}, 500 \mathrm{~K} \cdot \mathrm{min}^{-1}, 600 \mathrm{~K} \cdot \mathrm{min}^{-1}$, $700 \mathrm{~K} \cdot \mathrm{min}^{-1}$ and $800 \mathrm{~K} \cdot \mathrm{min}^{-1}$, respectively. In the second stage, the obtained residual char was cooled to room temperature first, and then the mass loss of char at different oxygen concentrations was obtained by changing the concentration of oxygen in the carrier gas from $1 \%$ to $20 \%$. The flow rate was $100 \mathrm{~mL} \cdot \mathrm{min}^{-1}$, and the temperature increased from room temperature to $873 \mathrm{~K}$ with a heating rate of $10 \mathrm{~K} \cdot \mathrm{min}^{-1}$.

\subsection{Tobacco pyrolysis and combustion experiment}

The schematic diagram of the pyrolysis and combustion experiment is shown in Figure 1. Approximately $1.0 \mathrm{~g}$ of tobacco sample was used. The quartz sample tube was flushed out by the carrier gas for $5 \mathrm{~min}$. The applied carrier gas was $2 \% \mathrm{O}_{2}+98 \% \mathrm{~N}_{2}, 10 \% \mathrm{O}_{2}+90 \% \mathrm{~N}_{2}$ and air, respectively. The tobacco sample was heated up from room temperature to the target temperature at the heating rate of $20 \mathrm{~K} \cdot \mathrm{s}^{-1}$. When the target temperature was reached, the tobacco sample was held for $5 \mathrm{~min}$. The gas flow rate was maintained at $2.0 \mathrm{~L} \cdot \mathrm{min}^{-1}$, which proved high enough to eliminate the smoke from the tube quickly. The "tar" was trapped in a condensing system using a Cambridge filter pad, which was placed on the outlet side of the furnace, while $\mathrm{CO}$ was detected online by smoke analyzer (J2KN, rbr, Iserlohn, Germany). Each experiment was performed twice with good repeatability in order to obtain an average of "tar" and CO data.

\subsection{Gas temperature measurement}

The gas temperature measurement system is shown in Figure 2. Eight thermocouples were inserted into the center of the cigarette, their locations started at $22 \mathrm{~mm}$ from the lighting end of the cigarette. The temperature data at specific locations during the smoking process were collected online by software.
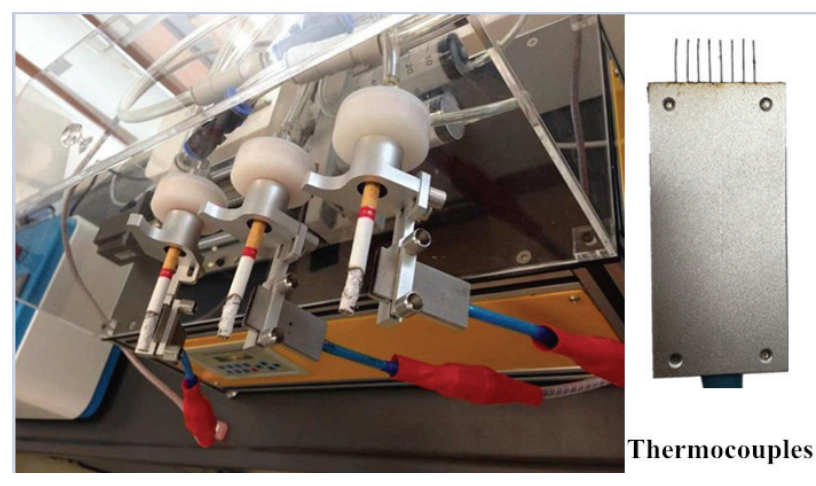

Figure 2. Gas temperature measurement system.

\section{MODEL DESCRIPTION}

\subsection{Computational domains}

The implementation of the model was carried out in a custom version of FLUENT's structured mesh solver, FLUENT 14.0 (28). The cigarette model was simplified as a two-dimensional model due to the cylindrical axis symmetric structure. The simulation domain was a central plane through the cigarette 
Table 2. Parameters and values related to each domain.

\begin{tabular}{|c|c|c|c|c|}
\hline Domain & Parameter & Definition & Unit & Value \\
\hline \multirow{13}{*}{ 1) } & $\rho_{\mathrm{s} 0}$ & Initial solid density & $\mathrm{kg} \cdot \mathrm{m}^{-3}$ & $740(12)$ \\
\hline & $\varphi$ & Porosity & 1 & 0.7 \\
\hline & $C_{p, s}$ & Specific heat of solid & $\mathrm{kJ} \cdot \mathrm{kg}^{-1} \cdot \mathrm{K}^{-1}$ & $1.043(12)$ \\
\hline & $C_{p, g}$ & Specific heat of gas & $\mathrm{kJ} \cdot \mathrm{kg}^{-1} \cdot \mathrm{K}^{-1}$ & $1.004(12)$ \\
\hline & $k_{s}$ & Solid conductivity & $\mathrm{W} \cdot \mathrm{m}^{-1} \cdot \mathrm{K}^{-1}$ & $0.316(12)$ \\
\hline & $k_{g}$ & Gas conductivity & $\mathrm{W} \cdot \mathrm{m}^{-1} \cdot \mathrm{K}^{-1}$ & $0.0242(12)$ \\
\hline & $\varepsilon$ & Emissivity of tobacco & 1 & $0.98(12)$ \\
\hline & $d_{\text {pore }}$ & Pore diameter & $\mathrm{m}$ & $5.75 \times 10^{-4}(12)$ \\
\hline & $H_{\text {evaporation }}$ & Water evaporation heat & $\mathrm{kJ} \cdot \mathrm{kg}^{-1}$ & $-2.2572 \times 10^{3}(12)$ \\
\hline & $H_{\text {combustion }}$ & Char combustion heat & $\mathrm{kJ} \cdot \mathrm{kg}^{-1}$ & $1.757 \times 10^{4}(12)$ \\
\hline & $v$ & Flow velocity & $\mathrm{m} / \mathrm{s}$ & 0 \\
\hline & $K_{u t}$ & Permeability of unburned tobacco & $\mathrm{m}^{2}$ & $5.6 \times 10^{-10}(18)$ \\
\hline & $K_{b t}$ & Permeability of burned tobacco & $\mathrm{m}^{2}$ & $10^{5}(18)$ \\
\hline \multirow[t]{5}{*}{ 2) } & $K_{u p}$ & Permeability of unburned cigarette paper & $\mathrm{m}^{2}$ & $5 \times 10^{-15}$ \\
\hline & $K_{b p}$ & Permeability of burned cigarette paper & $m^{2}$ & $10^{5}(18)$ \\
\hline & $d_{p}$ & Aerosol particle diameter & $\mathrm{m}$ & $4.4 \times 10^{-7}(19)$ \\
\hline & $d_{f}$ & Single fiber diameter & $\mathrm{m}$ & $2.51 \times 10^{-5}(19)$ \\
\hline & $D_{t}$ & Total denier of filter & $\mathrm{g} \cdot(9000 \mathrm{~m})^{-1}$ & 35000 \\
\hline \multirow{7}{*}{ 3) } & $D_{s}$ & Denier of per single fiber & $\mathrm{g} \cdot(9000 \mathrm{~m})^{-1}$ & 3 \\
\hline & $C_{\text {fiber }}$ & Crimping ratio of fibers & 1 & 0.17 \\
\hline & $S_{\text {filter }}$ & Cross-sectional area of filter rod & $\mathrm{m}^{2}$ & $4.899 \times 10^{-5}$ \\
\hline & $T_{\text {filter }}$ & Filter temperature & $\mathrm{K}$ & 288 \\
\hline & $K_{\text {filter }}$ & Permeability of filter & $\mathrm{m}^{2}$ & $2.5 \times 10^{-10}(18)$ \\
\hline & $T$ & Ambient temperature & $\mathrm{K}$ & 288 \\
\hline & $P$ & Ambient gas pressure & $\mathrm{kPa}$ & 101.3 \\
\hline \multirow[t]{3}{*}{ 4) } & $\rho_{g 0}$ & Initial gas density & $\mathrm{kg} \cdot \mathrm{m}^{-3}$ & 1.225 \\
\hline & $W_{O 2}$ & Mass fraction of $\mathrm{O}_{2}$ & $\%$ & 23 \\
\hline & $W_{N^{2}}$ & Mass fraction of $\mathrm{N}_{2}$ & $\%$ & 77 \\
\hline
\end{tabular}

(4)

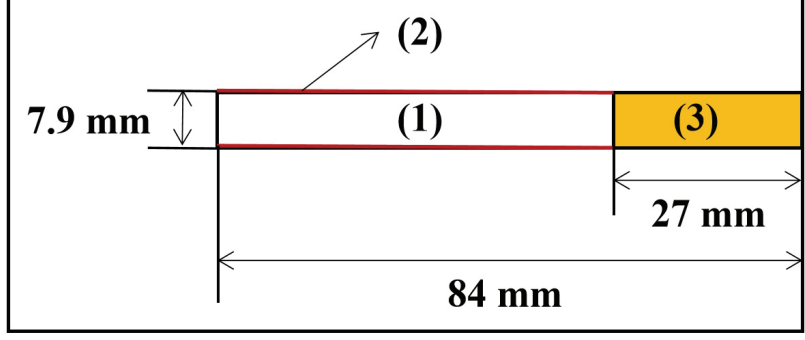

Figure 3. The geometry of the computational domains.

1) Tobacco rod; 2) Cigarette paper; 3) Filter rod; 4) External environment.

containing the longitudinal axis of the cigarette, as shown in Figure 3. There are four computational domains. The tobacco rod, cigarette paper and filter rod domains consisted of porous media. In the external environment, the pressure, temperature and gas composition were fixed at ambient conditions. A non-uniform structured mesh of 15854 control volumes was used in the domains, and the meshes near the surfaces were refined. Domain 1) was divided into 2790 grids ( 99 for the $\mathrm{x}$-axis and 30 for the $y$-axis) while domains 2) and 3) were divided into 738 and 720 grids separately. A number of important parameters and values related to each domain are shown in Table 2.
Domain 1) was the point source of energy and mass, which included the tobacco pyrolysis and combustion reaction kinetics. The tobacco was consumed and produced char, ash, and smoke, meanwhile releasing energy. Domain 2) affected the resistance to gas flow entering from the cigarette paper. Domain 3) covered the filtration model of the aerosols across the filter. Domain 4) is the external environment. All the exchange of heat, mass and momentum among the four domains were calculated based on the laminar flow model with energy equation and the species transport models with the effect of diffusion.

\subsection{Initial, boundary, and ignition conditions}

The initial pressure, temperature and gas composition were also set at ambient conditions within the entire computational domains. Tobacco and cigarette paper were initialized in the unburned state. The outside boundary of the Domain 4) was set as pressure outlet. The mouth end of the cigarette was set as the velocity inlet. The flow velocity was prescribed depending on the International Organization for Standardization smoking regime (ISO 3308) with $35-\mathrm{mL}$ puffs of $2 \mathrm{~s}$ duration, and a rate of one puff every $60 \mathrm{~s}$.

To ignite the cigarette, the temperature at the tip of the cigarette was raised to $1000 \mathrm{~K}$, and $35 \mathrm{~mL}$ air was drawn for two seconds. After this ignition period, the pre-programmed smoking regime was applied. 


\subsection{Tobacco pyrolysis reaction kinetics}

Accurate pyrolysis reaction kinetics are necessary to reasonably predict the yield of char, the fuel for the combustion process. The differential thermal gravity (DTG) curve of tobacco pyrolysis at $300 \mathrm{~K} \cdot \mathrm{min}^{-1}$ is presented in Figure 4 . The pyrolysis DTG curve can be approximated by five Gaussian peaks (R1-R5), so the tobacco is considered as consisting of five precursors. They are moisture, volatiles, hemicellulose, cellulose and lignin, which is consistent with the results reported in (20). According to the area percentages, the mass fractions $f_{p, j}$ for each pre cursor are listed in Table 3.

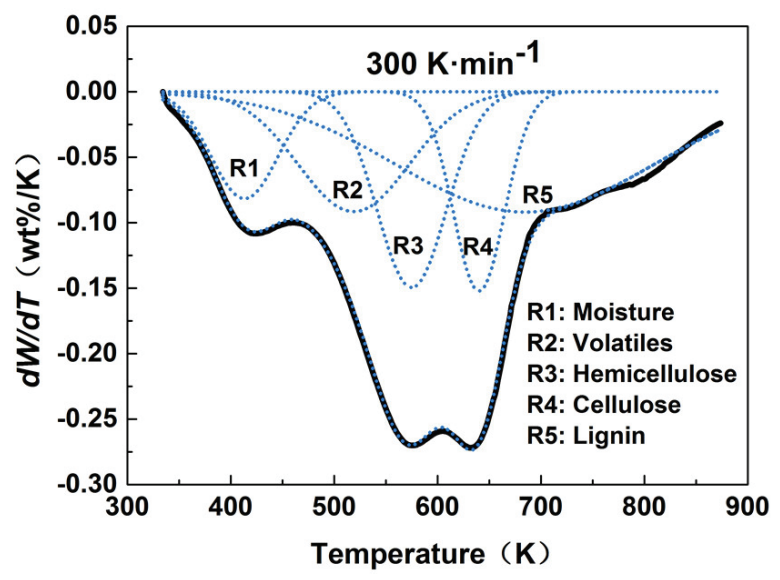

Figure 4. DTG of tobacco pyrolysis.

The pyrolysis of tobacco can be regarded as the parallel reactions of five precursors $(21,22)$. The pyrolysis kinetics of each precursor are expressed by Arrhenius equation:

$$
\frac{\partial \alpha_{p, j}}{\partial t}=A_{p, j} \exp \left(-\frac{E_{p, j}}{R T_{s}}\right)\left(1-\alpha_{p, j}\right)^{n_{p, j}}
$$

where $\alpha_{p, j}(\%)$ is the conversion ratio of the $j^{\text {th }}$ precursor, $t$ (min) is the time, $A_{p, j}\left(\mathrm{~min}^{-1}\right)$ is the $j^{\text {th }}$ reaction pre-exponential factor, $E_{p, j}\left(\mathrm{~kJ} \cdot \mathrm{mol}^{-1}\right)$ is the $j^{\text {th }}$ reaction activation energy, $T_{s}(\mathrm{~K})$ is the solid temperature, $R\left(8.314 \mathrm{~J} \cdot \mathrm{mol}^{-1} \cdot \mathrm{K}^{-1}\right)$ is the universal gas constant, $n_{p, j}$ is $j^{\text {th }}$ reaction order.

For reactions that are heterogeneous and non-isothermal with $\beta=d T_{s} / d t$, equation [1] can be rewritten as:

$$
\frac{\partial \alpha_{p, j}}{\partial T_{s}}=\frac{A_{p, j}}{\beta} \exp \left(-\frac{E_{p, j}}{R T_{s}}\right)\left(1-\alpha_{p, j}\right)^{n_{p, j}}
$$

where $\beta\left(\mathrm{K} \cdot \mathrm{min}^{-1}\right)$ is the heating rate. A wide range of heating rates was applied, but mostly at much lower heating rates $\left(10 \mathrm{~K} \cdot \mathrm{min}^{-1}-100 \mathrm{~K} \cdot \mathrm{min}^{-1}\right)$ than are actually present in a cigarette during smoldering and puffing. Therefore, the heating rate range was extended to $800 \mathrm{~K} \cdot \mathrm{min}^{-1}$ in this study. Figure 5 shows the approximated Gaussian peaks of five precursors at different heating rates. As seen from it, the effects of heating rate on pyrolysis reactions of five precursors are not the same. Hence, the pyrolysis kinetics of each precursor can be expressed by a modified Arrhenius which contains a calibration factor of the heating rate $m_{p, j}$ (20):

$$
\frac{\partial \alpha_{p, j}}{\partial T_{s}}=\frac{A_{p, j}}{\beta^{m_{p, j}}} \exp \left(-\frac{E_{p, j}}{R T_{s}}\right)\left(1-\alpha_{p, j}\right)^{n_{p, j}}
$$

The conversion ratio of the $j^{\text {th }}$ precursor $\alpha_{p, j}(\%)$ is defined as:

$\alpha_{p, j}=\frac{W_{p, j 0}-W_{p, j}}{f_{p, j}\left(W_{p 0}-W_{p f}\right)}$

where the initial mass percentage of the $j^{\text {th }}$ precursor is $W_{p, j 0}=100 \%$, the initial mass percentage of tobacco is $W_{p 0}=100 \%$, the final mass percentage of tobacco is $W_{p f}=30.83 \%$, measured by the TG experiment of tobacco pyrolysis, $W_{p, j}(\%)$ is the mass percentage of the $j^{\text {th }}$ precursor.

Based on equation [4], the mass loss rate of each precursor can be given by:

$$
\begin{aligned}
& \frac{\partial W_{p, j}}{\partial T_{s}}=-f_{p, j}\left(W_{p 0}-W_{p f}\right) \frac{\partial \alpha_{p, j}}{\partial T_{s}}= \\
& -f_{p, j}\left(W_{p 0}-W_{p f}\right) \frac{A_{p, j}}{\beta^{m_{p, j}}} \exp \left(-\frac{E_{p, j}}{R T_{s}}\right)\left(1-\alpha_{p, j}\right)^{n_{p, j}}
\end{aligned}
$$

The overall mass loss rate would be the sum of each precursor mass loss rate:

$$
\frac{\partial W_{p}}{\partial T_{s}}=\sum_{j=1}^{5} \frac{\partial W_{p, j}}{\partial T_{s}}
$$

where $W_{p}(\%)$ is the mass percentage of tobacco. Inserting equation [5] into equation [6]:

$$
\begin{aligned}
& \frac{\partial W_{p}}{\partial T_{s}}=-\sum_{j=1}^{5} f_{p, j}\left(W_{p 0}-W_{p f}\right) \frac{A_{p, j}}{\beta^{m_{p, j}}} \\
& \exp \left(-\frac{E_{p, j}}{R T_{s}}\right)\left(1-\alpha_{p, j}\right)^{n_{p, j}}
\end{aligned}
$$

In order to determine the kinetic parameters of each precursor, denoting the experimental data by $\left(\frac{\partial W_{p}}{\partial T}\right)^{\text {asp }}$ and the calculated data by $\left(\frac{\partial W_{p}}{\partial T_{s}}\right)^{\text {calc }}$ which can be calculated by equations [7] and equation [8]:

$$
\alpha_{p, j i+1}=\alpha_{p, j i}-\frac{\left(\frac{\partial W_{p, j i}}{\partial T_{s}}\right)^{c a l c} \partial T_{s}}{f_{p, j}\left(W_{p 0}-W_{p f}\right)}(i=1,2, \ldots . . N)
$$

where $N$ is the number of experimental points, the initial conversion ratio of the $j^{\text {th }}$ precursor $\alpha_{p, j l}(\%)$ is assumed to be $0 \%$.

The unknown kinetic parameters $\left(A_{p, j}, E_{p, j}, n_{p, j}\right.$, and $\left.m_{p, i}\right)$ are searched at which the determination coefficient $\left(R^{2}\right)$ is maximal. 
Table 3. Kinetic parameters of tobacco pyrolysis.

\begin{tabular}{cccccccc}
\hline Parameters & Unit & $\mathrm{R} 1$ & $\mathrm{R} 2$ & $\mathrm{R} 3$ & $\mathrm{R} 4$ & $\mathrm{R} 5$ \\
\hline$f_{p, j}$ & $\%$ & 9.52 & 17.71 & 18.04 & 13.58 & 41.16 \\
$A_{p, j}$ & $\mathrm{~min}^{-1}$ & $1.47 \times 10^{5}$ & $1.48 \times 10^{8}$ & $1.82 \times 10^{10}$ & $1.21 \times 10^{13}$ & 0.4538 \\
$E_{p, j}$ & $\mathrm{~kJ} \cdot \mathrm{mol}^{-1}$ & 31.09 & 60.81 & 91.48 & 133.48 & 25.78 \\
$n_{p, j}$ & - & 1.06 & 1.28 & 1.21 & 1.25 & 0.76 \\
$m_{p, j}$ & - & 1.24 & 1.54 & 1.48 & 1.49 & -0.04 \\
& & & $R^{2}=0.9821$ & & & \\
\hline
\end{tabular}
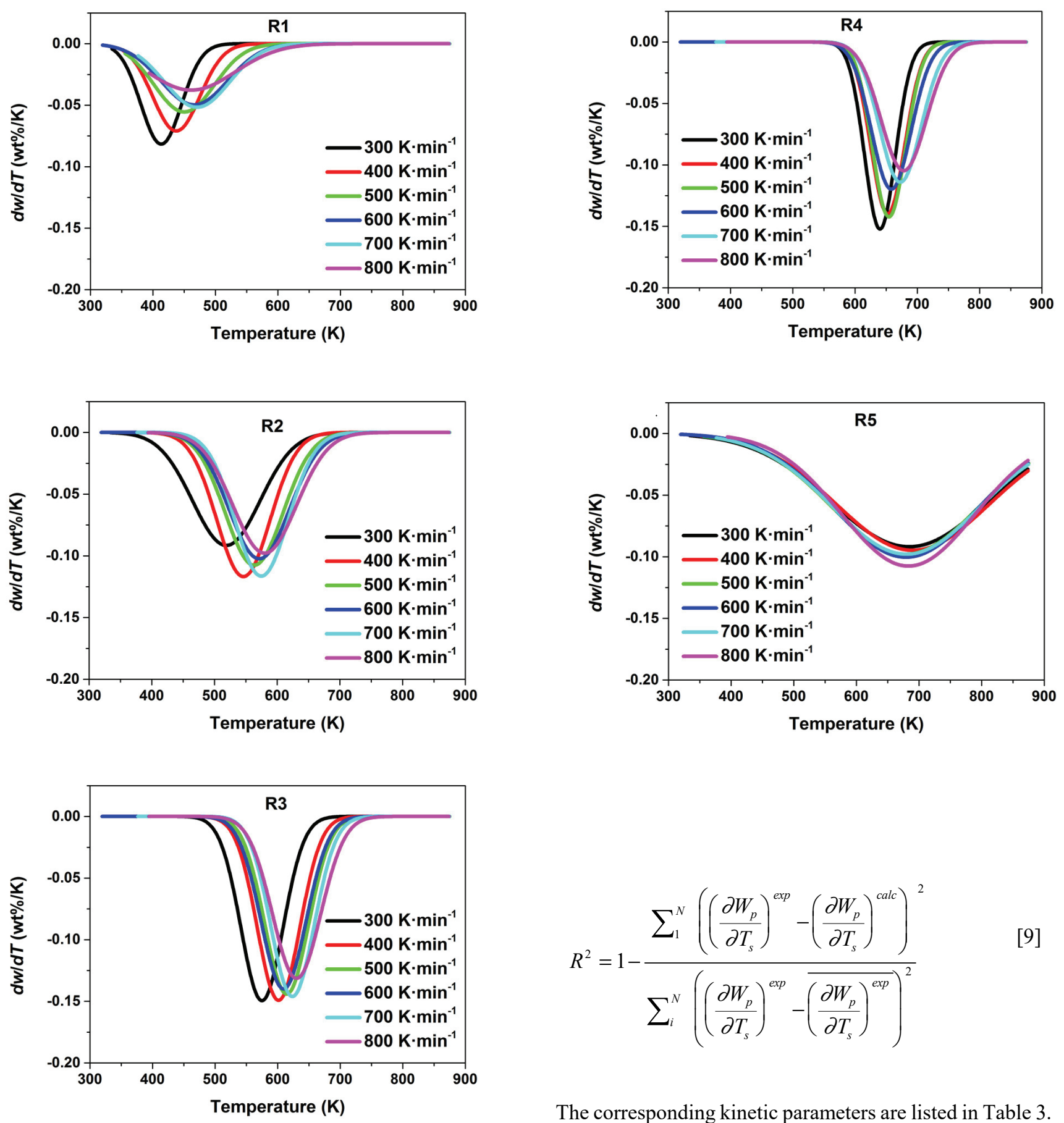

$$
R^{2}=1-\frac{\sum_{1}^{N}\left(\left(\frac{\partial W_{p}}{\partial T_{s}}\right)^{e x p}-\left(\frac{\partial W_{p}}{\partial T_{s}}\right)^{\text {calc }}\right)^{2}}{\sum_{i}^{N}\left(\left(\frac{\partial W_{p}}{\partial T_{s}}\right)^{\exp }-\overline{\left(\frac{\partial W_{p}}{\partial T_{s}}\right)^{e x p}}\right)^{2}}
$$

Figure 5. Approximated Gaussian peaks of five precursors at different heating rates.

The corresponding kinetic parameters are listed in Table 3. The experimental DTG curves and the fitted DTG curves of tobacco pyrolysis at different heating rates are shown in Figure 6, and they are in a good agreement. 

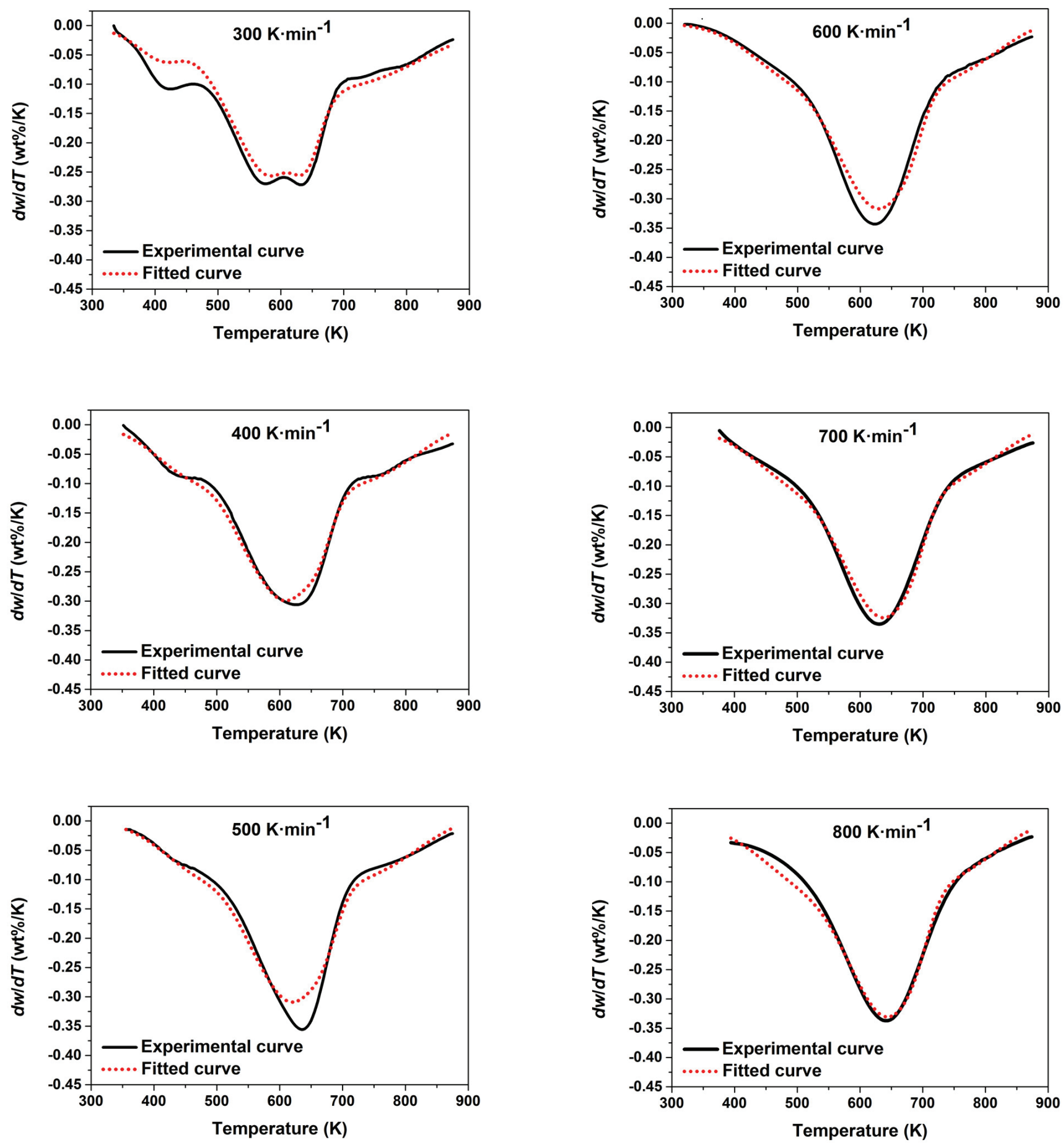

Figure 6. Comparison between the experimental DTG curves and the fitted DTG curves of the tobacco pyrolysis reaction at different heating rates.

\subsection{Char combustion reaction kinetics}

The char is formed through the pyrolysis of tobacco and consumed in an oxidation reaction. Reasonable char combustion reaction kinetics are critical for the prediction of the heat generation as they are the driving force for the flameless combustion process.

The char combustion kinetics can be expressed by the Arrhenius equation with $\beta=d T_{s} / d t$ :

$$
\begin{aligned}
& \frac{\partial \alpha_{c}}{\partial T_{s}}=\frac{A_{c}}{\beta} \exp \left(-\frac{E_{c}}{R T_{s}}\right)\left(1-\alpha_{c}\right)^{n_{c}}\left(\rho_{O_{2}}\right)^{n_{o}}= \\
& \frac{A_{c}}{\beta} \exp \left(-\frac{E_{c}}{R T_{s}}\right)\left(1-\alpha_{c}\right)^{n_{c}}\left(\rho_{g 0} W_{O_{2}}\right)^{n_{o}}
\end{aligned}
$$

where $\alpha_{c}(\%)$ is the conversion ratio of char, $\rho_{O_{2}}\left(\mathrm{~kg} \cdot \mathrm{m}^{-3}\right)$ is the oxygen density in gas mixture, $\rho_{\mathrm{g} 0}\left(\mathrm{~kg} \cdot \mathrm{m}^{-3}\right)$ is the initial gas density, $W_{O_{2}}(\%)$ is the mass fraction of oxygen, $A_{c}\left(\mathrm{~min}^{-1}\right)$ is 
the char oxidation reaction pre-exponential factor, $E_{c}\left(\mathrm{~kJ} \cdot \mathrm{mol}^{-1}\right)$ is the char oxidation reaction activation energy, $n_{c}$ is the reaction order of char, which is assumed to be $1, n_{o}$ is the reaction order of oxygen.

The conversion ratio of $\operatorname{char} \alpha_{c}(\%)$ is defined as:

$\alpha_{c}=\frac{W_{c 0}-W_{c}}{W_{c 0}-W_{c f}}$

where the initial mass percentage of char is $W_{c 0}=100 \%$, the final mass percentage of char is $W_{c f}=52.93 \%$, measured by the TG experiment of char combustion, $W_{c}$ $(\%)$ is the mass percentage of char.

Based on equation [11], the mass loss rate of char can be given by:

$\frac{\partial W_{c}}{\partial T_{c}}=-\left(W_{c 0}-W_{c f}\right) \frac{\partial \alpha_{c}}{\partial T_{s}}$

$=-\left(W_{c 0}-W_{c f}\right) \frac{A_{c}}{\beta} \exp \left(-\frac{E_{c}}{R T_{s}}\right)\left(1-\alpha_{c}\right)\left(\rho_{g 0} W_{O_{2}}\right)^{n_{o}}$

Inside a burning cigarette, the supply rate of oxygen is the dominant factor in determining the rate of char combustion and heat generation. Therefore, the char combustion kinetics need to be set up at different oxygen mass fractions $W_{O^{2}}(\%)$. In this study, $W_{O^{2}}=1 \%, 2 \%, 3 \%, 5 \%, 10 \%, 15 \%$ and $20 \%$ were considered.

In order to determine the kinetic parameters of char, denoting the experimental data by $\left(\frac{\partial W_{c}}{\partial T_{s}}\right)^{\exp }$ and the calculated data by $\left(\frac{\partial W_{c}}{\partial T_{s}}\right)^{c a l c}$ which can be calculated by equation [12] and equation [13]:

$\alpha_{c, i+1}=\alpha_{c, i}-\frac{\left(\frac{\partial W_{c, i}}{\partial T_{s}}\right)^{\mathrm{calc}} \partial T_{s}}{W_{c 0}-W_{c f}}(i=1,2, \ldots . . N)$

where the initial conversion ratio of char $\alpha_{c, 1}(\%)$ is assumed to be $0 \%$.

The unknown kinetic parameters $\left(A_{c}, E_{c,}\right.$ and $n_{O_{2}}$ are searched at which the determination coefficient $\left(R^{2}\right)$ is maximal. However, the fitting results showing the reaction order of oxygen cannot be the same at different $W_{O^{2}}$. Therefore, the oxygen mass fraction is divided into three ranges $\left(0 \% \leq W_{O^{2}} \leq 2 \%, 2 \%<W_{O^{2}} \leq 10 \%\right.$ and $10 \%$ $\left.<W_{\mathrm{O}_{2}} \leq 23 \%\right)$ and the corresponding kinetic parameters are listed in Table 4.

The experimental DTG curves and the fitted DTG curves of char combustion at different oxygen concentrations are shown in Figure 7, and they are in a reasonable agreement.

\subsection{Transport system}

\subsubsection{Mass transport}

The source terms of solid and gas species required in the mass transport equations could be obtained by calculating their density change rates.

The source term of all precursors, $S_{\text {precursors }}\left(\mathrm{kg} \cdot \mathrm{m}^{-3} \cdot \mathrm{min}^{-1}\right)$, was calculated as the sum of five precursors consumed during the tobacco pyrolysis reaction.

$S_{\text {precursors }}=\frac{\partial \rho_{p}}{\partial t} \sum_{j=1}^{5} \frac{\partial \rho_{p, j}}{\partial t}$

where $\rho_{p}\left(\mathrm{~kg} \cdot \mathrm{m}^{-3}\right)$ is the total density of five precursors, $\rho_{p, j}$ $\left(\mathrm{kg} \cdot \mathrm{m}^{-3}\right)$ is the density of $j^{\text {th }}$ precursor, which can be calculated by:

$\rho_{p, j}=f_{p, j} \rho_{s 0}\left(1-\alpha_{p, j}\right)$

Based on equation (15), the density change rate of each precursor can be written as:

$\frac{\partial \rho_{p, j}}{\partial t}=-f_{p, j} \rho_{s 0} \frac{\partial \alpha_{p, j}}{\partial t}=-\beta f_{p, j} \rho_{s 0} \frac{\partial \alpha_{p, j}}{\partial t}$

where

$\frac{\partial \alpha_{p, j}}{\partial T_{s}}=\frac{A_{p, j}}{\beta^{m_{p, j}}} \exp \left(-\frac{E_{p, j}}{R T_{s}}\right)\left(1-\alpha_{p, j}\right)^{n_{p, j}}$ see [3]

Therefore, the source term of all precursors is solved in the following form:

$$
\begin{aligned}
& S_{\text {precursors }}= \\
& -\beta \rho_{s 0} \sum_{j=1}^{5} f_{p, j} \frac{A_{p, j}}{\beta^{m_{p, j}}} \exp \left(-\frac{E_{p, j}}{R T_{s}}\right)\left(\frac{\rho_{p, j}}{f_{p, j} \rho_{s 0}}\right)^{n_{p, j}}
\end{aligned}
$$

Char is primarily formed through the pyrolysis reaction and then consumed in combustion reaction, therefore the source term of char, $S_{\text {char }}\left(\mathrm{kg} \cdot \mathrm{m}^{-3} \cdot \mathrm{min}^{-1}\right)$, consists of two terms, as shown in equation [18]. The first term represents the rate of formation, while the second term indicates the rate of consumption.

\begin{tabular}{|c|c|c|c|c|}
\hline \multicolumn{2}{|c|}{$W_{O}$ range } & $0 \% \leq W_{0} \leq 2 \%$ & $2 \%<W_{0} \leq 10 \%$ & $10 \%<W_{0} \leq 23 \%$ \\
\hline Parameters & Unit & $W_{0}=1 \%, 2 \%$ & $W_{O}=3 \%, 5 \%, 10 \%$ & $W_{O}=15 \%, 20 \%$ \\
\hline$A_{c}$ & $\min ^{-1}$ & $1.48 \times 10^{7}$ & $4.26 \times 10^{7}$ & $8.30 \times 10^{7}$ \\
\hline$E_{c}$ & $\mathrm{~kJ} \cdot \mathrm{mol}^{-1}$ & 91.04 & 111.20 & 116.31 \\
\hline$n_{0}$ & - & 1.09 & 0.43 & 0.36 \\
\hline & $\mathrm{R}^{2}$ & 0.9441 & 0.9574 & 0.9537 \\
\hline
\end{tabular}

Table 4. Kinetic parameters of char combustion. 

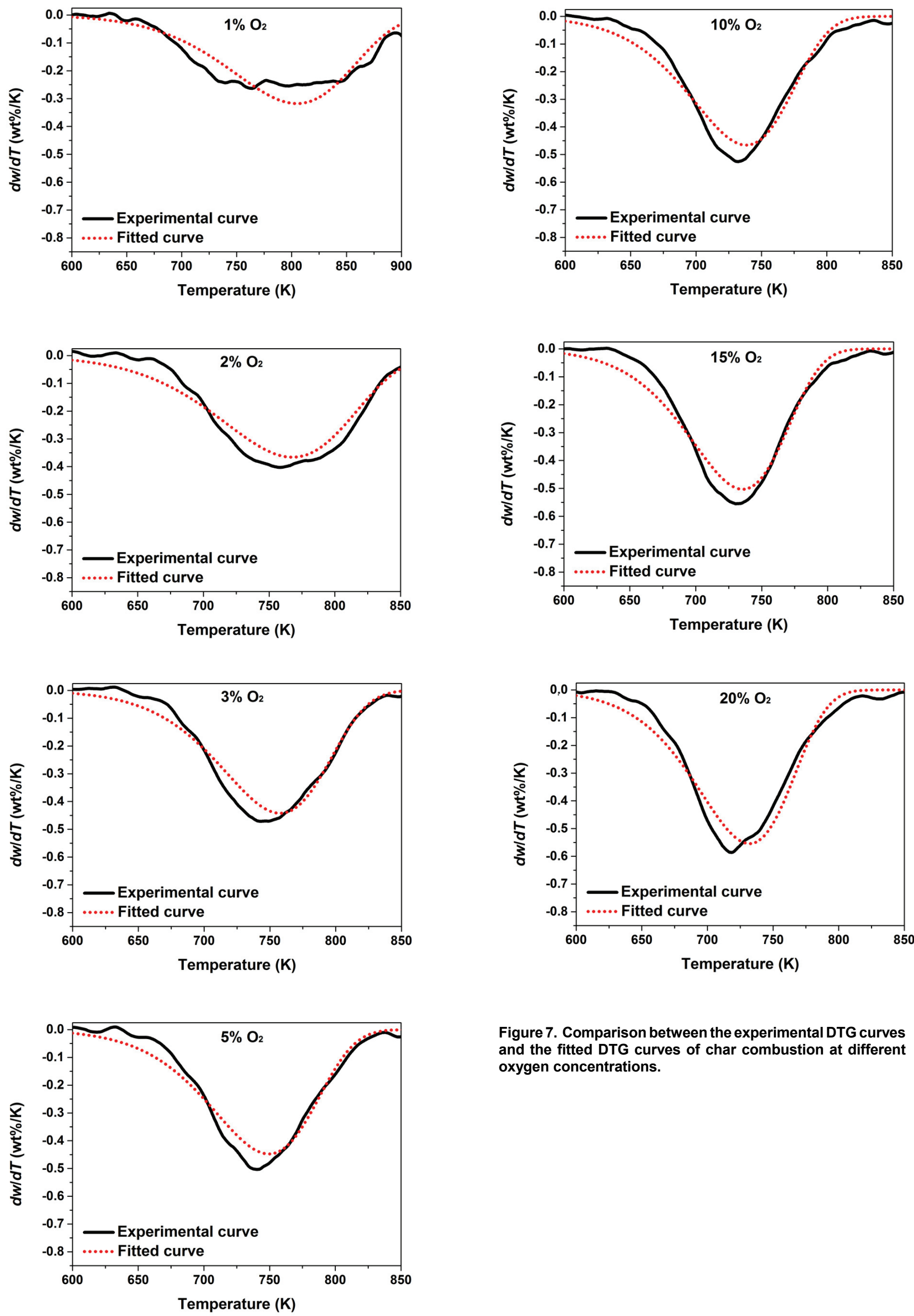

Figure 7. Comparison between the experimental DTG curves and the fitted DTG curves of char combustion at different oxygen concentrations. 
$S_{c h a r}=\frac{\partial \rho_{c}^{\prime}}{\partial t}=-f_{c} \frac{\partial \rho_{p}}{\partial t}+\frac{\partial \rho_{c}}{\partial t}$

where $\rho_{c}^{\prime}\left(\mathrm{kg} \cdot \mathrm{m}^{-3}\right)$ is the overall char density, $f_{c}=30.83 \%$ is the residual mass fraction of tobacco pyrolysis reaction measured by the TG experiment, and $\rho_{c}\left(\mathrm{~kg} \cdot \mathrm{m}^{-3}\right)$ is the combustible char density, which can be calculated by:

$\rho_{c}=\rho_{c, t}\left(1-\alpha_{c}\right)$

where the total combustible char density after complete pyrolysis is $\rho_{c, t}=f_{c} \rho_{s 0}\left(\mathrm{~kg} \cdot \mathrm{m}^{-3}\right)$.

Based on equation [19], the combustible char density change rate can be written as:

$\frac{\partial \rho_{c}}{\partial t}=-\rho_{c, t} \frac{\partial \alpha_{c}}{\partial t}=-\beta \rho_{c, t} \frac{\partial \alpha_{c}}{\partial T_{s}}$

where

$$
\frac{\partial \alpha_{c}}{\partial T_{s}}=\frac{A_{c}}{\beta} \exp \left(-\frac{E_{c}}{R T_{s}}\right)\left(1-\alpha_{c}\right)^{n_{c}}\left(\rho_{O_{2}}\right)^{n_{o}} \quad \text { see [10] }
$$

Finally, the source term of char is solved in the following form:

$S_{c h a r}=-f_{c} \frac{\partial \rho_{p}}{\partial t}-\beta \rho_{c, t} \frac{A_{c}}{\beta} \exp \left(-\frac{E_{c}}{R T_{s}}\right) \frac{\rho_{c}}{\rho_{c, t}}\left(\rho_{O_{2}}\right)^{n_{o}}$

where

$\rho_{c}=\rho_{c, l a s t}^{\prime}-f_{c} \frac{\partial \rho_{p}}{\partial t} \partial t$

$\rho_{c, \text { last }}^{\prime}\left(\mathrm{kg} \cdot \mathrm{m}^{-3}\right)$ is the overall char density at the last moment calculated by FLUENT, $\rho_{O^{2}}\left(\mathrm{~kg} \cdot \mathrm{m}^{-3}\right)$ is the oxygen density in the gas mixture.

From equation [21], we conclude that in order to calculate the rate of char combustion, the oxygen distribution needs to be known. Here, a single-step oxidation reaction leading to product species is assumed as proposed by ROSTAMI et al. (12). Oxygen is the gas phase species being transported. The source term of oxygen, $S_{\text {oxygen }}\left(\mathrm{kg} \cdot \mathrm{m}^{-3} \cdot \mathrm{min}^{-1}\right)$ can be directly obtained from the stoichiometric ratio of the com- bustible char and oxygen.

$S_{\text {oxygen }}=\frac{\partial \rho_{O_{2}}}{\partial t}=n_{O_{2}}^{\prime} \frac{\partial \rho_{c}}{\partial t}=$

$-n_{O_{2}}^{\prime} A_{c} \exp \left(\frac{E_{c}}{R T_{s}}\right) \rho_{c}\left(\rho_{O_{2}}\right)^{n_{o}}$

where the stoichiometric coefficient for oxygen consumption is $n_{\mathrm{O} 2}^{\prime}=1.65$ (12).

Since the transport of oxygen depends critically on its ability to diffuse through the gas phase, it is important to include the correct dependence of diffusivity on temperature. The oxygen diffusivity is taken from (12):

$D=D_{0}\left(\frac{T_{g}}{273}\right)^{1.75}$

$D_{0}=0.677 D_{g} \Phi^{1.18}$

where $D_{0}\left(\mathrm{~m}^{2} \cdot \mathrm{s}^{-1}\right)$ is the mass diffusivity in the porous media at $273 \mathrm{~K}$ and $101.3 \mathrm{kPa}, T_{g}(\mathrm{~K})$ is the gas temperature, the oxygen diffusion in nitrogen is $D_{g}=2 \times 10^{-5} \mathrm{~m}^{2} \cdot \mathrm{s}^{-1}$ and a tobacco rod filling with a total void fraction is $\Phi=0.85$ (12). Ash is produced by the char combustion reaction. The source term of ash, $S_{a s h}\left(\mathrm{~kg} \cdot \mathrm{m}^{-3} \cdot \mathrm{min}^{-1}\right)$, can be written as:

$$
\begin{aligned}
& S_{a s h}=\frac{\partial \rho_{a s h}}{\partial t}=-f_{a s h} \frac{\partial \rho_{c}}{\partial t}= \\
& f_{a s h} A_{c} \exp \left(-\frac{E_{c}}{R T_{s}}\right) \rho_{c}\left(\rho_{O_{2}}\right)^{n_{o}}
\end{aligned}
$$

where $\rho_{\text {ash }}\left(\mathrm{kg} \cdot \mathrm{m}^{-3}\right)$ is the ash density, and $f_{\text {ash }}=52.93 \%$ is the residual mass fraction of char combustion measured by the TG experiment.

Using the tobacco pyrolysis and combustion experimental platform, the released amounts of "tar" and CO at different reaction conditions were obtained, as shown in Figure 8. Based on the data, the mathematical relationships of "tar" and $\mathrm{CO}$ at different temperatures and oxygen mass fractions

\begin{tabular}{|c|c|c|}
\hline Temperature range & $W_{o}$ range & "Tar" (mg.g $\left.{ }^{-1}\right)$ \\
\hline \multirow{3}{*}{$423 \mathrm{~K} \leq \mathrm{T} \leq 623 \mathrm{~K}$} & $0 \% \leq W_{0}<5 \%$ & $Y_{1}=-0.0049 T^{2}+5.8838 T-1617\left(R^{2}=0.8990\right)$ \\
\hline & $5 \% \leq W_{0^{*}}<15 \%$ & $Y_{1}=-0.0048 T^{2}+5.7621 T-1580\left(R^{2}=0.9034\right)$ \\
\hline & $15 \% \leq W_{0^{*}} \leq 23 \%$ & $Y_{1}=-0.0061 T^{2}+7.1210 T-1911\left(R^{2}=0.9734\right)$ \\
\hline $623 \mathrm{~K} \mathrm{~T} \leq 1273 \mathrm{~K}$ & $0 \% \leq W_{O^{*}} \leq 23 \%$ & 160 \\
\hline Temperature range & $W_{o^{\prime}}$ range & $\mathrm{CO}\left(\mathrm{mg} \cdot \mathrm{g}^{-1}\right)$ \\
\hline \multirow{3}{*}{$423 \mathrm{~K} \leq \mathrm{T} \leq 1273 \mathrm{~K}$} & $0 \% \leq W_{0}<5 \%$ & $Y_{2}=0.2132 T-89.19\left(R^{2}=0.9575\right)$ \\
\hline & $5 \% \leq W_{0}<15 \%$ & $Y_{2}=0.2630 T-107.32\left(R^{2}=0.9608\right)$ \\
\hline & $15 \% \leq W_{0} \leq 23 \%$ & $Y_{2}=0.2516 T-90.41\left(R^{2}=0.9333\right)$ \\
\hline
\end{tabular}
were set up, as shown in Table 5.

Table 5. Mathematical relationships of "tar" and $\mathrm{CO}$ at different temperatures and oxygen mass fractions. 

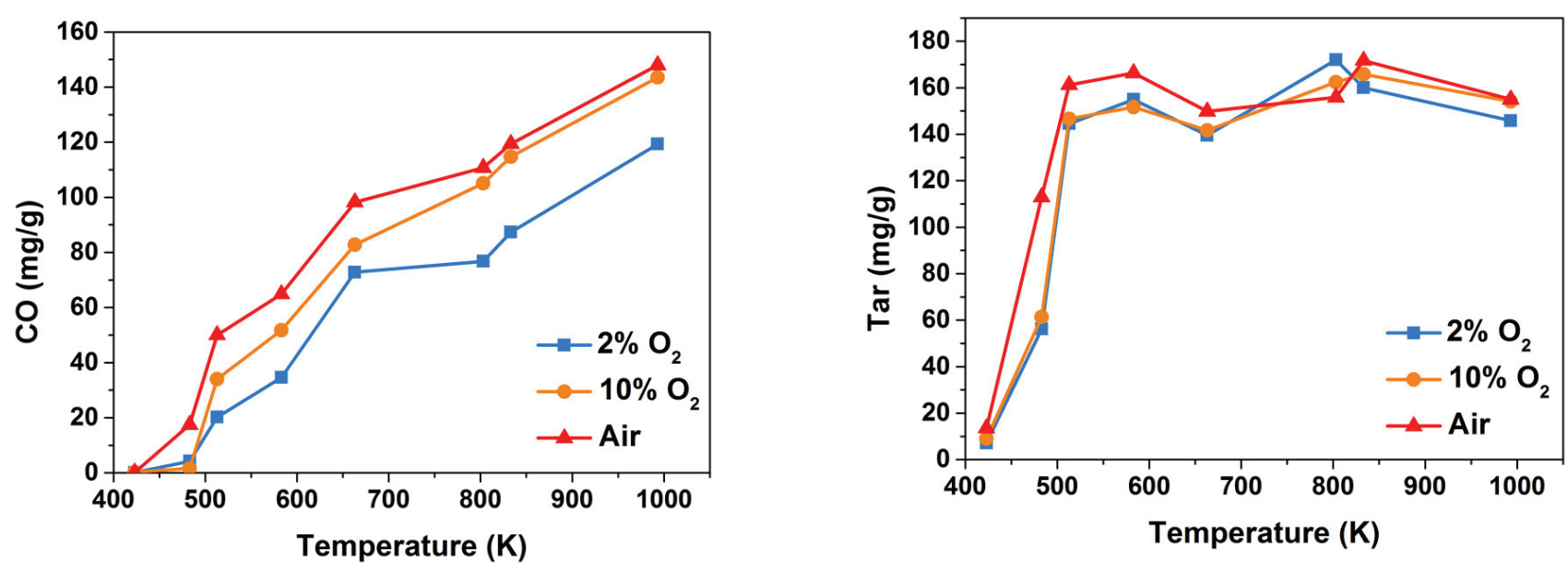

Figure 8. Release amounts of "tar" and $\mathrm{CO}$ at different reaction conditions.

According to $Y_{1}\left(\mathrm{mg} \cdot \mathrm{g}^{-1}=10^{-3}\right)$ and $Y_{2}\left(\mathrm{mg} \cdot \mathrm{g}^{-1}=10^{-3}\right)$, the source terms of "tar", $S_{\text {"tar" }}\left(\mathrm{kg} \cdot \mathrm{m}^{-3} \cdot \mathrm{min}^{-1}\right)$, and $\mathrm{CO}$, $S_{C O}\left(\mathrm{~kg} \cdot \mathrm{m}^{-3} \cdot \mathrm{min}^{-1}\right)$, are given, respectively:

$$
\begin{aligned}
& S_{\text {tar" }}=-10^{-3} Y_{1} \frac{\partial \rho_{s}}{\partial t} \\
& S_{C O}=-10^{-3} Y_{2} \frac{\partial \rho_{s}}{\partial t}
\end{aligned}
$$

where:

$\frac{\partial \rho_{s}}{\partial t}=\frac{\partial \rho_{p}}{\partial t}+\frac{\partial \rho_{c}^{\prime}}{\partial t}+\frac{\partial \rho_{a s h}}{\partial t}$

$\rho_{s}\left(\mathrm{~kg} \cdot \mathrm{m}^{-3}\right)$ is the density of solid species including five precursors, char and ash.

\subsubsection{Energy transport}

The solid and gas phase energy equation are:

$$
\begin{aligned}
& \frac{\partial\left((1-\varphi) \rho_{s} C_{p, s} T_{s}\right)}{\partial t}=\vec{\nabla}\left[k_{s, e f f} \vec{\nabla} T_{s}\right]+ \\
& h A_{v}\left(T_{g}-T_{s}\right)+S_{\text {solid }} \\
& \frac{\partial\left(\varphi \rho_{g} C_{p, g} T_{g}\right)}{\partial t}+\vec{\nabla}\left[\rho_{g} C_{p, g} T_{g} \vec{v}\right] \\
& =\vec{\nabla}\left[k_{g, e f f} \vec{\nabla} T_{g}\right]+h A_{v}\left(T_{s}-T_{g}\right)
\end{aligned}
$$

respectively, where the porosity of tobacco rod is assumed to be a constant, $\varphi=0.7, \rho_{g}\left(\mathrm{~kg} \cdot \mathrm{m}^{-3}\right)$ is the gas density, $C_{p, s}$ $\left(\mathrm{kJ} \cdot \mathrm{kg}^{-1} \cdot \mathrm{K}^{-1}\right)$ is the specific heat of the solid phase, $C_{p, g}$ $\left(\mathrm{kJ} \cdot \mathrm{kg}^{-1} \cdot \mathrm{K}^{-1}\right)$ is the specific heat of the gas phase.

$k_{g, e f f}\left(\mathrm{~W} \cdot \mathrm{m}^{-1} \cdot \mathrm{K}^{-1}\right)$ and $k_{s, \text { eff }}\left(\mathrm{W} \cdot \mathrm{m}^{-1} \cdot \mathrm{K}^{-1}\right)$ are the effective heat conductivity in the gas phase / solid phase, which can be given by:

$$
\begin{aligned}
& k_{g, e f f}=\varphi k_{g} \\
& k_{s, e f f}=\left(k_{s}+4 \varepsilon \sigma T_{s}^{3} d_{p o r e}\right)(1-\varphi)
\end{aligned}
$$

where $k_{g}\left(\mathrm{~W} \cdot \mathrm{m}^{-1} \cdot \mathrm{K}^{-1}\right)$ is the gas conductivity, $k_{s}$ $\left(\mathrm{W} \cdot \mathrm{m}^{-1} \cdot \mathrm{K}^{-1}\right.$ ) is the solid conductivity, $\varepsilon$ is the emissivity of tobacco, $d_{\text {pore }}(\mathrm{m})$ is the pore diameter, Stefan-Boltzmann constant is $\sigma=5.67 \times 10^{-8} \mathrm{~W} \cdot \mathrm{m}^{-2} \cdot \mathrm{K}^{-4}$.

The solid-gas interfacial area to volume is given as:

$$
A_{v}=\frac{A}{V}=\frac{6 \varphi}{d_{\text {pore }}}
$$

$h$ is the solid-gas heat transfer coefficient, which can be calculated by the following equation:

$$
N u=\frac{h d_{t}}{k_{g}}=2+1.1 \operatorname{Re}^{0.6} \operatorname{Pr}^{0.333}
$$

where $N u$ is the Nußelt number, $R e$ is the Reynolds number, and $P r$ is the Prandtl number.

The heat source term of solid $S_{\text {solid }}$ represents the sum of heat of evaporation and char combustion. The heat of pyrolysis reaction was assumed to be very small and did not play a significant role:

$$
S_{\text {solid }}=H_{\text {evaporation }} \frac{d \rho_{w}}{d t}+H_{\text {combustion }} \frac{d \rho_{c}}{d t}
$$

where $H_{\text {evaporation }}\left(\mathrm{kJ} \mathrm{kg}^{-1}\right)$ is the water evaporation heat and $H_{\text {combustion }}\left(\mathrm{kJ} \cdot \mathrm{kg}^{-1}\right)$ is the char combustion heat.

\subsubsection{Momentum transport}

The tobacco rod and cigarette paper are considered as porous media with known permeability. The source term of momentum represents the added pressure drop due to the presence of solid phase, which is given by: 
$\vec{s}_{\text {momentum }}=-\left(\frac{\mu_{g} \vec{v}}{K_{\text {media }}}+\frac{1}{2} C \rho_{s}|\vec{v}| \vec{v}\right)$

where $\overrightarrow{\mathrm{v}}\left(\mathrm{m} \cdot \mathrm{s}^{-1}\right)$ is the specific velocity $C$ is an empirical constant governing the magnitude of the inertial term, which is assumed zero.

$\mu_{g}\left(\mathrm{~kg} \cdot \mathrm{s}^{-1} \cdot \mathrm{m}^{-1}\right)$ is the gas dynamic viscosity, the effect of temperature on $\mu_{g}$ is accounted by using Sutherland's twocoefficient law:

$\mu_{g}=\frac{C_{1} T_{g}^{\frac{3}{2}}}{T_{g}+C_{2}}$

where $C_{1}=1.458 \times 10^{-6} \mathrm{~kg} \cdot \mathrm{s}^{-1} \cdot \mathrm{m}^{-1} \cdot \mathrm{K}^{1 / 2}$ and $C_{2}=110.4 \mathrm{~K}$ (14).

$K_{\text {media }}\left(\mathrm{m}^{2}\right)$ is the permeability of the porous media. For the permeability of tobacco $K_{t}\left(\mathrm{~m}^{2}\right)$, it was assumed to change linearly with the density of the unburned tobacco:

$K_{t}=K_{u t}(1-g)+K_{b t} g$

$g=-\frac{\rho_{s}-\rho_{s 0}}{\rho_{s 0}}$

where $g$ is an interpolation factor, $K_{u t}\left(\mathrm{~m}^{2}\right)$ is the permeability of unburned tobacco, $K_{b t}\left(\mathrm{~m}^{2}\right)$ is the permeability of burned tobacco.

\subsection{Theoretical filtration model of aerosols across the filter}

For single fibers, the filtration efficiency was calculated by the filtration mechanism model of aerosols in filters proposed by Du et al. (19), which includes four filtration efficiencies, such as the interception efficiency $\left(E_{I N}\right)$, the inertial impaction efficiency $\left(E_{I M}\right)$, the diffusion impaction efficiency $\left(E_{D}\right)$, and diffusion-inertial impaction efficiency $\left(E_{I D}\right)$.

Interception efficiency $\left(E_{I N}\right)$ can be calculated by:

$E_{I N}=\frac{f(G)}{2 K_{u}}$

$f(G)=\frac{1}{1+G}-(1+G)+2(1+G) \ln (1+G)$

$G=\frac{d_{p}}{d_{f}}$

$K_{u}=-\frac{\ln \alpha_{f}}{2}-\frac{3}{4}+\alpha_{f}-\frac{\alpha_{f}^{2}}{4}$

$\alpha_{f}=\frac{D_{t} \pi d_{f}^{2}\left(1+C_{\text {fiber }}\right)}{4 D_{s} S_{\text {filter }}}$

where $G$ is the dimensionless interception parameter, $K_{u}$ is the Kuwabara hydrodynamic factor, $\alpha_{f}$ is the solid fraction of filter, $d_{p}(\mathrm{~m})$ is the particle diameter, $d_{f}(\mathrm{~m})$ is the single fiber diameter, $D_{t}$ is the total denier of filter, $D_{s}$ is the denier of per single fiber, $C_{\text {fiber }}$ is the crimping ratio of fibers, $S_{\text {filter }}\left(\mathrm{m}^{2}\right)$ is the cross-sectional area of filter rod. Inertial impaction efficiency $\left(E_{I M}\right)$ can be calculated by:

$$
E_{I M}=\frac{(S t k) J}{2 K_{u}^{2}}
$$

$S t k=\frac{\rho_{g} d_{p}^{2} v}{18 \mu_{g} d_{f}}$

$J=\left(29.6-28 \alpha_{f}^{0.62}\right) G^{2}-27.5 G^{2.8}$

where $S t k$ is the Stokes number, $v\left(\mathrm{~m} \cdot \mathrm{s}^{-1}\right)$ is the gas velocity, $\mu_{g}\left(\mathrm{~kg} \cdot \mathrm{s}^{-1} \cdot \mathrm{m}^{-1}\right)$ is the gas dynamic viscosity, which can be calculated by equation [38].

Diffusion impaction efficiency $\left(E_{D}\right)$ can be calculated by:

$E_{D}=2.7 P e^{\frac{2}{3}}$

$P e=\frac{d_{f} v}{D_{p}}$

$D_{p}=\frac{K_{B} T_{\text {filter }}}{3 \pi \mu_{g} d_{p}}$

where $P e$ is the Peclet number, $D_{p}\left(\mathrm{~m}^{2} \cdot \mathrm{s}^{-1}\right)$ is the particle diffusion coefficient, the Stefan-Boltzmann constant is $K_{B}=1.38 \times 10^{-23} \mathrm{~J} \cdot \mathrm{K}^{-1}, T_{\text {filter }}(\mathrm{K})$ is the temperature of filter. Diffusion-inertial impaction efficiency $\left(E_{I D}\right)$ can be calculated by:

$E_{I D}=\frac{1.23 G^{\frac{2}{3}}}{\left(K_{u} P e\right)^{\frac{1}{2}}}$

The combined single fiber efficiency can be calculated as equation:

$\varepsilon_{s}=E_{I N}+E_{I M}+E_{D}+E_{I D}$

The overall filtration efficiency of a filter can be calculated from the single fiber efficiency by equation [23]:

$$
\varepsilon=1-\exp \left(-\frac{4 \alpha_{f} \varepsilon_{s} L_{f}}{\pi\left(1-\alpha_{f}\right) d_{f}}\right)
$$

where $L_{f}$ is the filter length, $0.027 \mathrm{~m}$. The overall filtration efficiency at different positions of the filter can be calculated by:

$$
\frac{d \varepsilon}{d L_{x}}=\frac{4 \alpha_{f} \varepsilon_{s}}{\pi\left(1-\alpha_{f}\right) d_{f}} \exp \left(-\frac{4 \alpha_{f} \varepsilon_{s} L_{x}}{\pi\left(1-\alpha_{f}\right) d_{f}}\right)
$$


Therefore, the source term of "tar" in the filter, $S_{\text {"tar" }}^{\prime}$ $\left(\mathrm{kg} \cdot \mathrm{m}^{-3} \cdot \mathrm{min}^{-1}\right)$ can be written as:

$$
\begin{aligned}
& S_{\text {tar" }}^{\prime}=f_{\text {"tar" }} \rho_{g} v \frac{d \varepsilon}{d L_{x}} \\
& =f_{\text {"tar" }} \rho_{g} v \frac{4 \alpha_{f} \varepsilon_{s}}{\pi\left(1-\alpha_{f}\right) d_{f}} \exp \left(-\frac{4 \alpha_{f} \mathcal{E}_{s} L_{x}}{\pi\left(1-\alpha_{f}\right) d_{f}}\right)
\end{aligned}
$$

The source term of "tar" in the combustion of cigarette has been established in Section 3.5.1 as:

$$
S_{" t a r "}=-10^{-3} Y_{1} \frac{\partial \rho_{s}}{\partial t}
$$

According to the source term equations, the flow of "tar" and air over the entire cross section of the cigarette at the inlet of the filter can be obtained in FLUENT. The ratio of the two is taken as the mass fraction of the "tar" at the inlet of the filter, $f_{\text {"tar" }}(\%)$.

The filtration efficiency of filter can be calculated by using the following equation:

$\eta=\frac{m_{i n}-m_{\text {out }}}{m_{\text {in }}}$

where $m_{i n}(\mathrm{mg})$ is the "tar" released at the inlet of the filter before puffing, $m_{\text {out }}(\mathrm{mg})$ is the "tar" released at the outlet of the filter after puffing.

\subsection{Numerical method}

The four domains were discretized into structured control volumes over which the conservation equations for mass, momentum, energy and chemical species were discretized. A non-uniform structured mesh of 15854 control volumes was used in the domains, and the meshes near the surfaces were refined. All the exchange of heat, mass and momentum among the four domains were based on the laminar flow model with the energy equation and species transport models with the effect of diffusion. Standard second-order spatial discretization schemes were used for convective operators, with a second-order upwind discretization of the diffusion terms. Based on that, the gaseous emission towards the environment was rapid compared with the emission within the cigarette. The cigarette burning process was assumed to be free of gravity effects which allowed us to use symmetrical conditions, hence considerably shortening the computation time.

The length of the time interval was controlled by the time scale of the reaction. The number of time steps was set to 60,000 , with a relative time step size of $0.01 \mathrm{~s}$. Typically 10 iterations per time step were required. The discretization of the unsteady terms was carried out using a second-order implicit scheme.

In FLUENT, the Navier-Stokes equation was solved for conservation of mass, momentum and energy and other scalars such as turbulence and the chemical species using a pressure-based solver. A pressure-based solver requires pressure-velocity coupling, thus the Semi-Implicit Method for Pressure Linked equations (SIMPLE) (24) algorithm was recommended in order to improve the rate of convergence and to reduce simulation time. Basically, the governing equations were coupled to each other in a manner that the solution process required iterations wherein the entire set of governing equations were solved repeatedly until the solution converged.

All equations were solved sequentially and iteratively in keeping with the FLUENT algorithms. The equations described above were incorporated through the usersubroutines available in FLUENT, though some manipulations were not possible through these subroutines and had to be carried out by making changes to the source.

\section{RESULTS AND DISCUSSIONS}

\subsection{Permeability of cigarette paper}

The permeability of cigarette paper plays an important and critical role during the cigarette burning process, especially the permeability of the cigarette paper behind the char line, which determines the resistance to the gas flow entering from the cigarette paper during puffing and consequently the char combustion rate.

The permeability of the cigarette paper increased almost exponentially with the temperature (25). We have reported that the pyrolysis temperature range of cigarette paper was $473 \mathrm{~K}-623 \mathrm{~K}$, and the temperature of the cigarette paper behind the char line could reach $623 \mathrm{~K}$ (26). Normally, the permeability of cigarette paper is measured at room temperature, but the actual permeability of the cigarette paper behind the char line was difficult to obtain. Hence, in this model, when the temperature of the cigarette paper was $<473 \mathrm{~K}$, the permeability of the unburned cigarette paper was $K_{u p}=5 \times 10^{-15} \mathrm{~m}^{2},(\approx 30 \mathrm{CU}$, the thickness of the cigarette paper was about $0.06 \mathrm{~mm})$, when the temperature of the cigarette paper was $>623 \mathrm{~K}$, the permeability of burned cigarette paper was $K_{b p}=10^{5} \mathrm{~m}^{2}(18)$. The cigarette paper behind the char line was set locating at the position where the temperature ranged from $473 \mathrm{~K}$ to $623 \mathrm{~K}$, and its permeability was $K_{p}$.

In order to obtain the proper $K_{p}$ in this model, four cases were considered, $K_{p}=5 \times 10^{-15} \mathrm{~m}^{2}, 10^{-9} \mathrm{~m}^{2}, 1.5 \times 10^{-9} \mathrm{~m}^{2}$ and $10^{-3} \mathrm{~m}^{2}$, namely cases $1,2,3$ and 4 . Figure 9 shows the char density fields in the four cases during puffing $(240 \mathrm{~s}$, $241 \mathrm{~s}$, and $242 \mathrm{~s}$ ). The development of the coal shape could be checked visually to verify the adequacy of the simulations. When $K_{p}=5 \times 10^{-15} \mathrm{~m}^{2}$, most char was consumed and could not form the combustion coal, resulting from most of the air flowing into the combustion center, leading to the acceleration of the char combustion reaction. In contrast, when $K_{p}=10^{-3} \mathrm{~m}^{2}$, the combustion coal was more obtuse and the shape nearly remained the same, which was due to most of the air entering from the cigarette paper behind the char line, resulting in the deceleration of the char combustion reaction.

These results show the two cases are unrealistic. When $K_{p}=10^{-9} \mathrm{~m}^{2}$ and $1.5 \times 10^{-9} \mathrm{~m}^{2}$, the shapes of combustion coals were conical, which was similar to the realistic situation. 

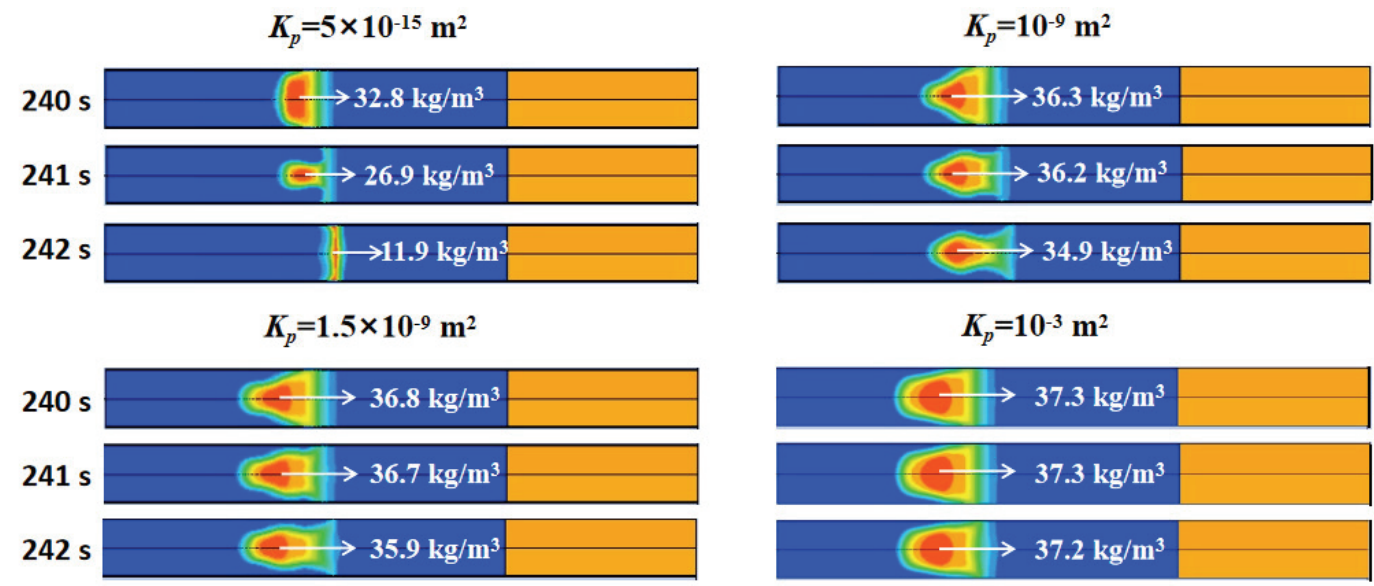

Figure 9. Density fields of char in four cases during puffing.

The proper value of $K_{p}$ was determined by matching the numerical and experimental results. Table 6 shows the numerical and experimental yields of "tar" and CO in the mainstream. It can be seen that case 3 has produced a good match with the experimental data. The predicted yields of "tar" and CO were $12.2 \mathrm{mg} / \mathrm{cig}$ and $14.6 \mathrm{mg} / \mathrm{cig}$, and the experimental values were $11.2 \mathrm{mg} / \mathrm{cig}$ and $13.2 \mathrm{mg} / \mathrm{cig}$, respectively, with relative deviations of $8.9 \%$ and $10.6 \%$, respectively. Therefore, $K_{p}=1.5 \times 10^{-9} \mathrm{~m}^{2}$ was used in the numerical simulations.

In practice, a full comparison of the experimental results with all predictions of the model is difficult. In order to check the validity of the proposed model, five criteria were chosen. These were: puff number, temperatures, flow velocity, filtration efficiency of the filter and the yields of "tar" and $\mathrm{CO}$ under different puff intensities.

\subsection{Validity of puff number}

Figure 10 shows the development of char density with time in case 3 . We see that the combustion cone has formed at $60 \mathrm{~s}$. As the combustion progresses, the shape of the combustion center becomes gradually more conical and moves in the smoldering direction, indicating that the cigarette can keep burning.

Figure 11 shows the permeability changes of the cigarette paper at different times in case 3 . It can be noticed that the changes in permeability of the cigarette paper were closely synchronized with the changes in char density, which indicates setting $K_{p}=1.5 \times 10^{-9} \mathrm{~m}^{2}$ when the surface temperature in the range of $473 \mathrm{~K}-623 \mathrm{~K}$ was reasonable.
From the ignition point to the point located $3 \mathrm{~mm}$ from the tipping paper (the length of the tipping paper of the actual cigarette was $31 \mathrm{~mm}$ ), the experimental puff number was 6.8. This model terminated smoking at $420.5 \mathrm{~s}$ when the char line was located at $50.0 \mathrm{~mm}$, the predicted puff number was 7.3. The agreement between the predicted and experimental puff numbers suggests that the burning speed predicted by the cigarette model is basically consistent with the actual cigarette burning speed.

\subsection{Validity of temperature}

Figure 12 shows the gas temperature fields during puffing ( $240 \mathrm{~s}, 241 \mathrm{~s}$, and $242 \mathrm{~s}$ ) in case 3 . It can be seen that the gas temperature increased rapidly, and the maximum gas temperature of the center of the cigarette combustion cone could rise up to $1292 \mathrm{~K}$ at $242 \mathrm{~s}$. In order to verify the accuracy of the predicted cigarette combustion temperature, the temperatures at specific positions were measured. Eight thermocouples were inserted into the center of the cigarette, at $22 \mathrm{~mm}, 24 \mathrm{~mm}, 26 \mathrm{~mm}, 28 \mathrm{~mm}, 30 \mathrm{~mm}, 32 \mathrm{~mm}, 34 \mathrm{~mm}$ and $36 \mathrm{~mm}$ from the lighting end of the cigarette, respectively. After igniting, the cigarette kept smoldering. When the char line migrated at $26 \mathrm{~mm}$, puffing started. The initial gas temperature at the $26-\mathrm{mm}$ position before puffing was $933 \mathrm{~K}$ as shown in Figure 13. In the cigarette combustion model, the cigarette also kept smoldering after ignition. When the predicted temperature at $26 \mathrm{~mm}$ reached $933 \mathrm{~K}$, a puff was simulated using the model. The real-time temperatures of the center of the cigarette at the corresponding positions were monitored.

Table 6. Comparison of the numerical and experimental results.

\begin{tabular}{|c|c|c|c|c|c|c|}
\hline & & Case 1 & Case 2 & Case 3 & Case 4 & Experimental \\
\hline \multirow{2}{*}{ “Tar” } & (mg/cig) & 15.8 & 14.1 & 12.2 & 5.1 & 11.2 \\
\hline & Relative deviation & $41.1 \%$ & $25.9 \%$ & $8.9 \%$ & $54.5 \%$ & - \\
\hline \multirow{2}{*}{$\mathrm{CO}$} & (mg/cig) & 21.1 & 17.3 & 14.6 & 5.6 & 13.2 \\
\hline & Relative deviation & $59.8 \%$ & $31.1 \%$ & $10.6 \%$ & $57.6 \%$ & - \\
\hline
\end{tabular}




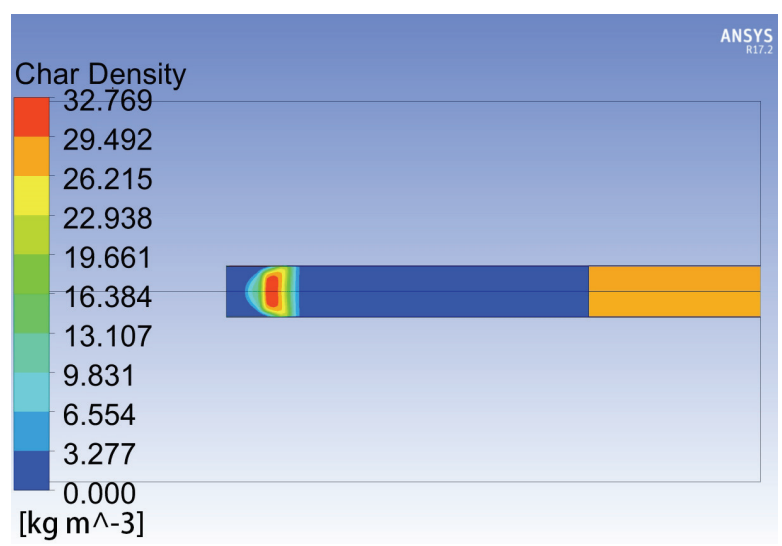

$60 \mathrm{~s}$

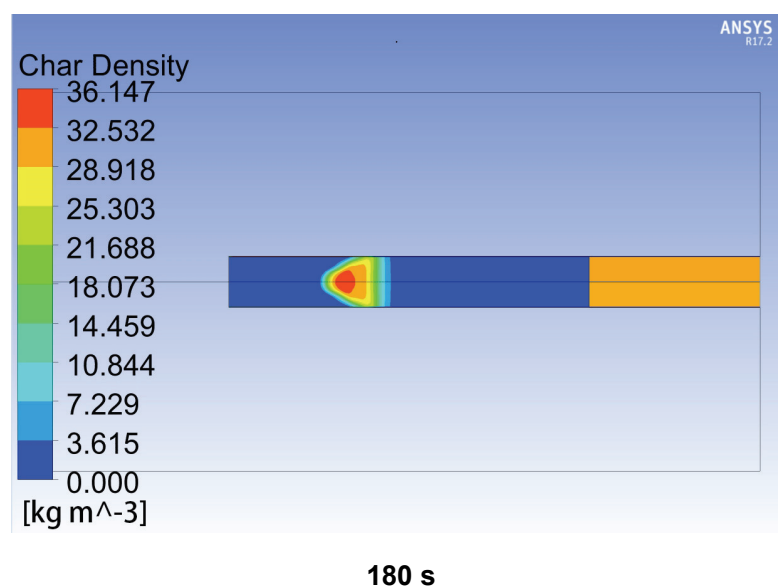

$180 \mathrm{~s}$
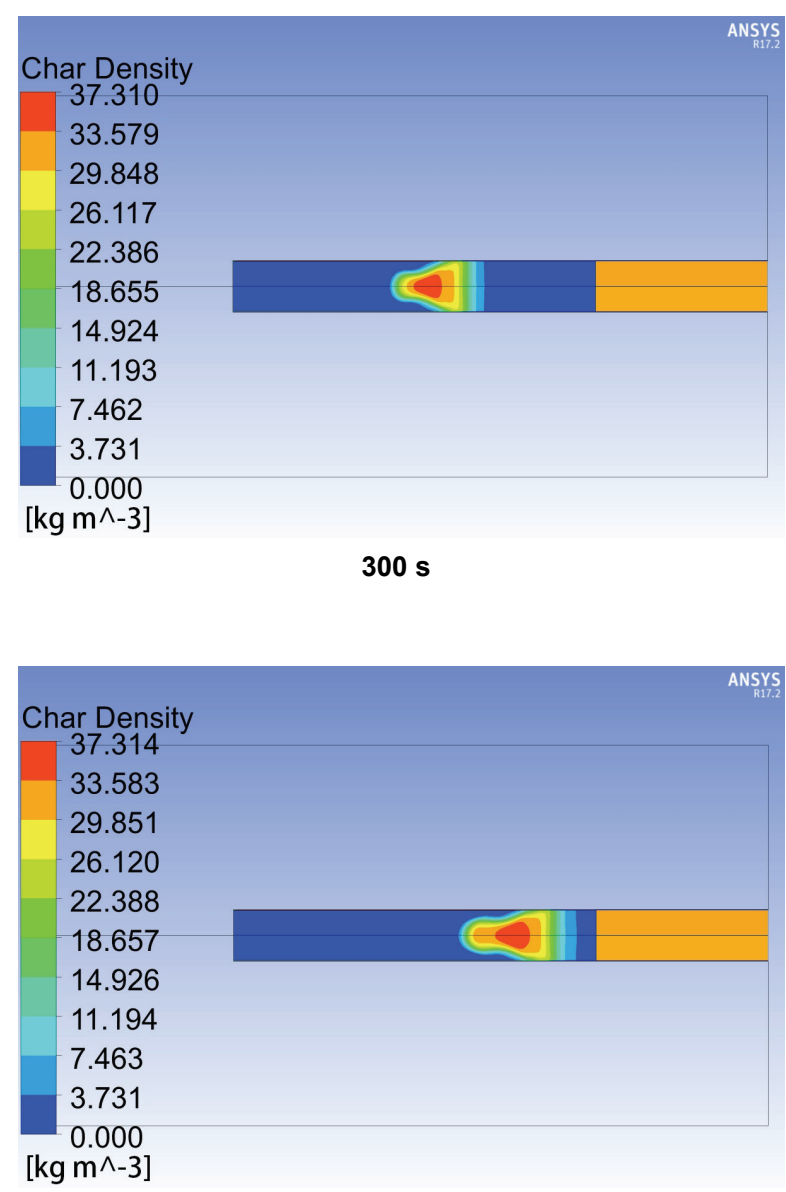

$420 \mathrm{~s}$

Figure 10. Density fields of char at different times (case 3).

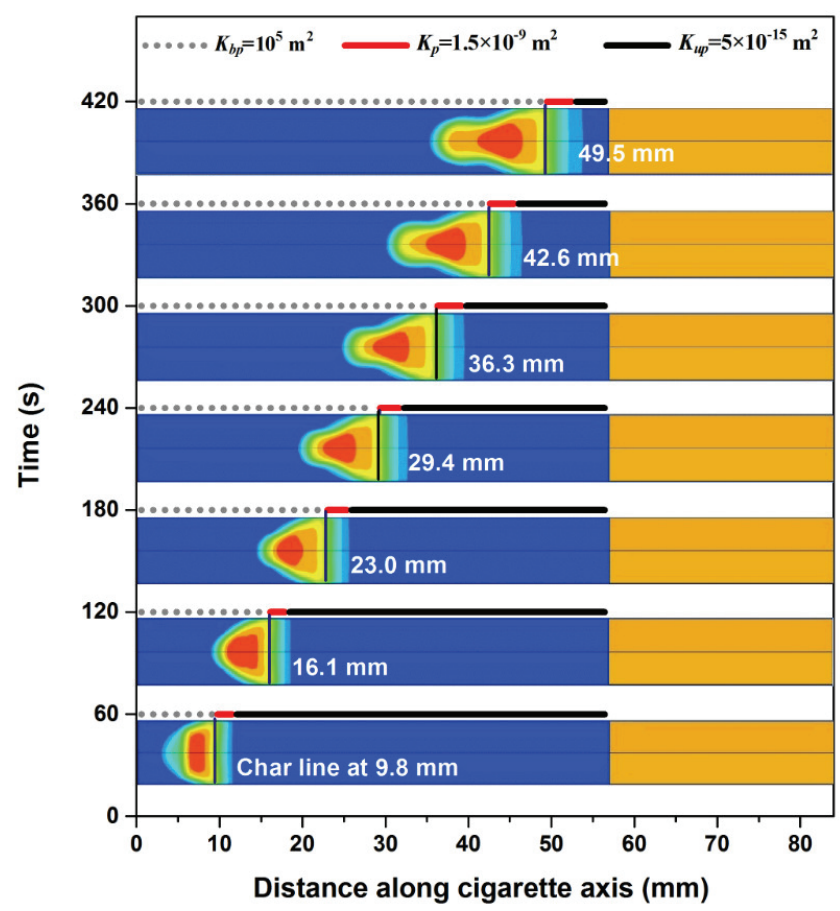

Figure 11. Permeability of the cigarette paper, char line and char density along the axis of the cigarette at different times (case 3). 
Figure 13 compares the predicted gas temperature at each position from $0 \mathrm{~s}$ to $350 \mathrm{~s}$ with the experimental data. Table 7 shows the standard root mean square error (NRMSE) of the predicted gas temperatures and experimental gas temperatures for eight positions, and the overall deviation was less than $18 \%$. The results show that this model has reproduced the basic features of the temperature distribution, and is also in good agreement with the experimental data quantitatively.

Table 7. NRMSE of the predicted gas temperatures and experimental gas temperatures for eight locations.

\begin{tabular}{l|c|c|c|c|c|c|c|c}
\hline Location & $22 \mathrm{~mm}$ & $24 \mathrm{~mm}$ & $26 \mathrm{~mm}$ & $28 \mathrm{~mm}$ & $30 \mathrm{~mm}$ & $32 \mathrm{~mm}$ & $34 \mathrm{~mm}$ & $36 \mathrm{~mm}$ \\
\hline NRMSE & $16.0 \%$ & $17.5 \%$ & $11.0 \%$ & $8.5 \%$ & $13.9 \%$ & $16.0 \%$ & $15.8 \%$ & $11.9 \%$ \\
\hline
\end{tabular}
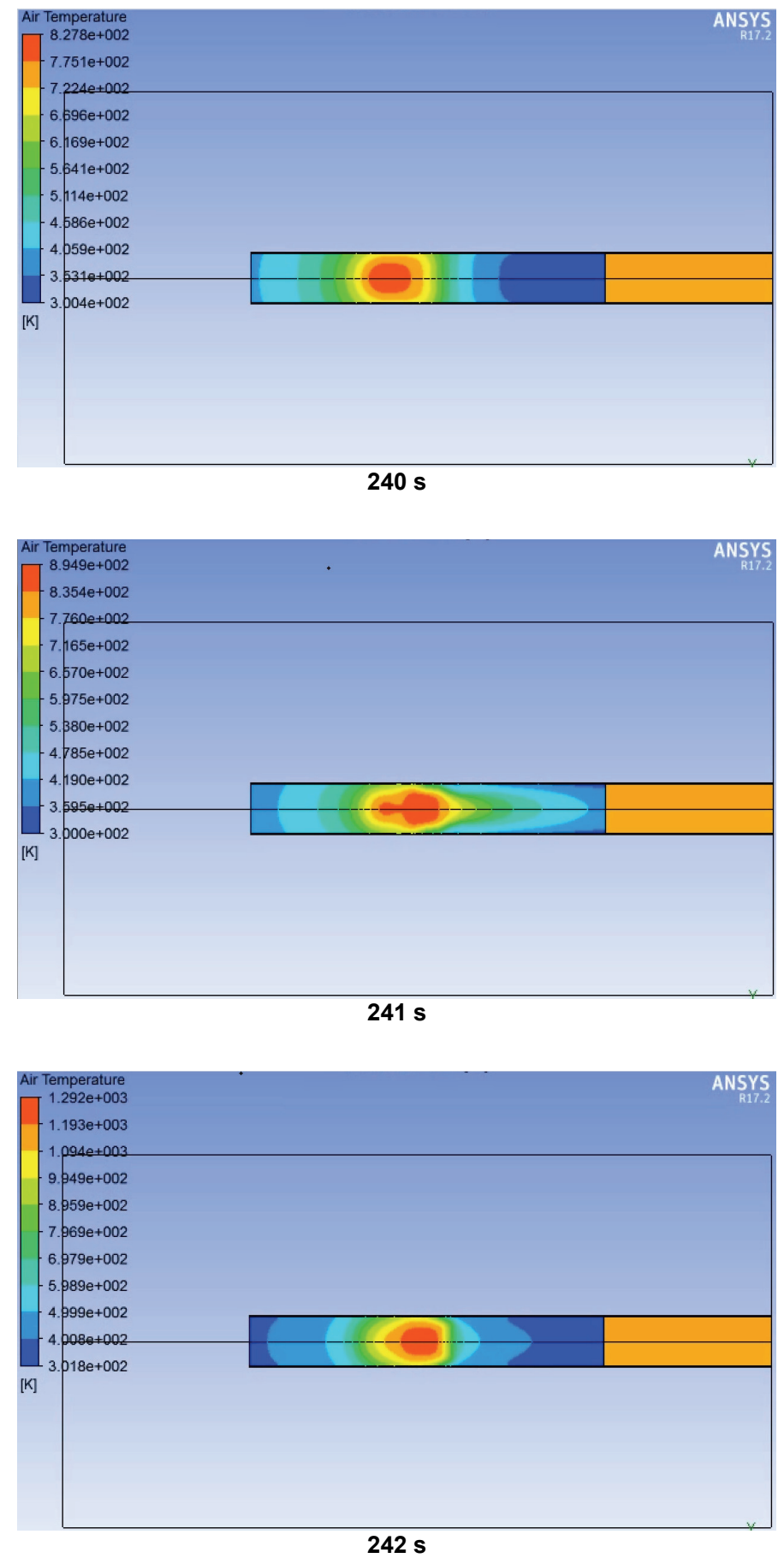

Figure 12. Gas temperature fields of cigarette during puffing (case 3). 

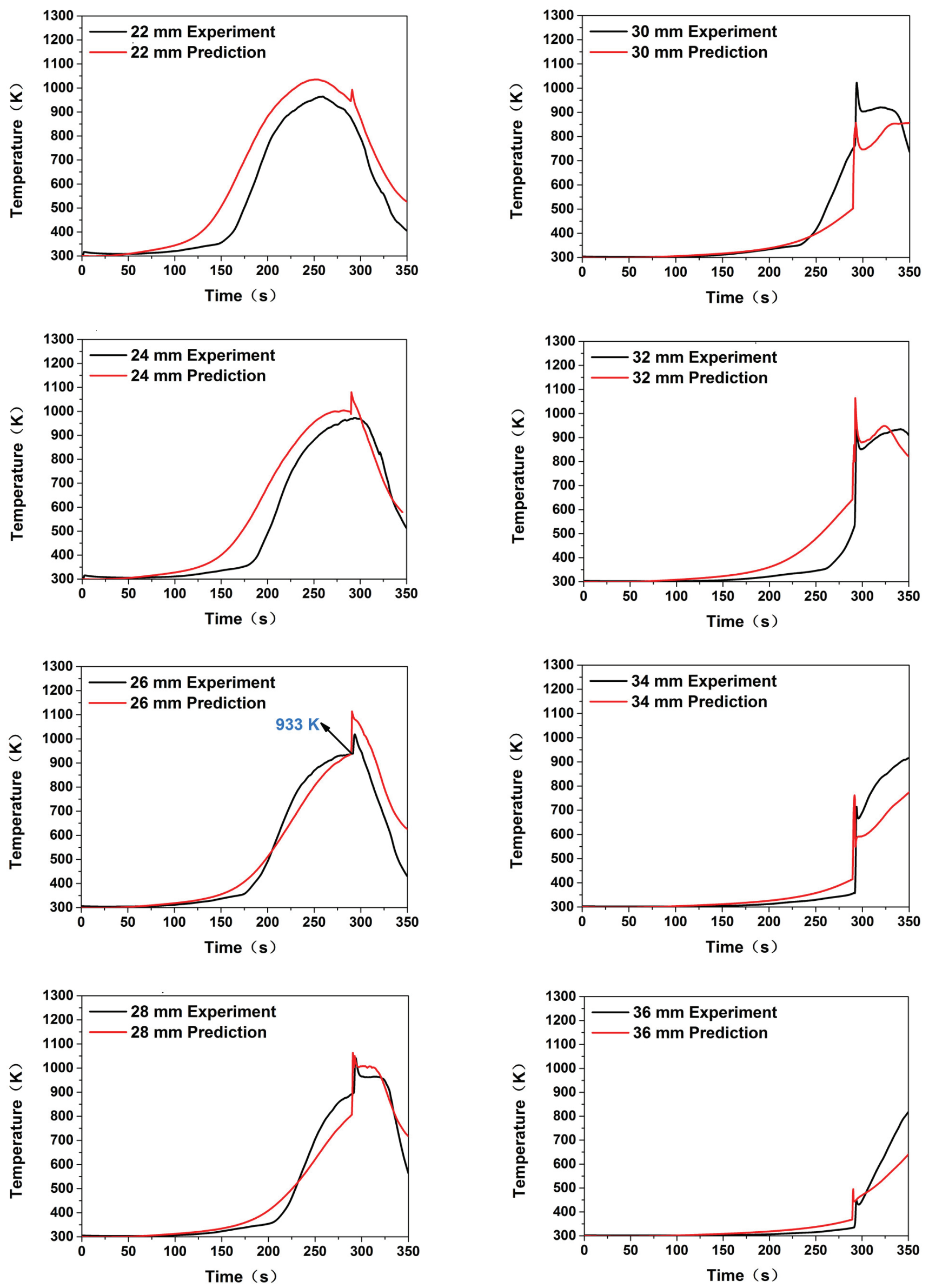

Figure 13. Comparison of experimental gas temperatures and predicted gas temperatures at different positions of a cigarette. 


\subsection{Validity of flow velocity}

Figure 14 shows the flow velocity fields during puffing ( $240 \mathrm{~s}, 241 \mathrm{~s}$, and $242 \mathrm{~s}$ ) in case 3 . It can be seen that the flow velocity increased at the first second, reached the maximum flow velocity at $241 \mathrm{~s}$, and then dropped significantly. From $241 \mathrm{~s}$ to $242 \mathrm{~s}$, the flow velocity near the cigarette paper area was higher than in the central region of the combustion cone. A similar tendency was experimentally observed by Li et al. (27). Because of the increase in the permeability of cigarette paper behind the char line, a large amount of flow avoids the center of the combustion cone and enters from the cigarette paper area.

The density fields of "tar" and CO during puffing (240 s, $241 \mathrm{~s}$, and $242 \mathrm{~s}$ ) in case 3 are shown in Figures 15 and 16.
It is clear from the figures that both "tar"- and CO-release amounts increased significantly during puffing. This situation could be explained from the above simulations based on the char density field, temperature field and flow velocity field. The main difference between smoldering and puffing is the increase in the flow velocity (Figure 14), which resulted in an increase of oxygen supply. Therefore the char combustion reaction rate increased while more heat was released and the temperature increased (Figure 12). After a temperature increase, the tobacco pyrolysis would be accelerated too and more tobacco would be involved in the reactions and produce more char for combustion. Thus, the rapid increase in "tar" and CO release can be attributed to the acceleration of the reactions due to the increase in flow velocity and temperature.
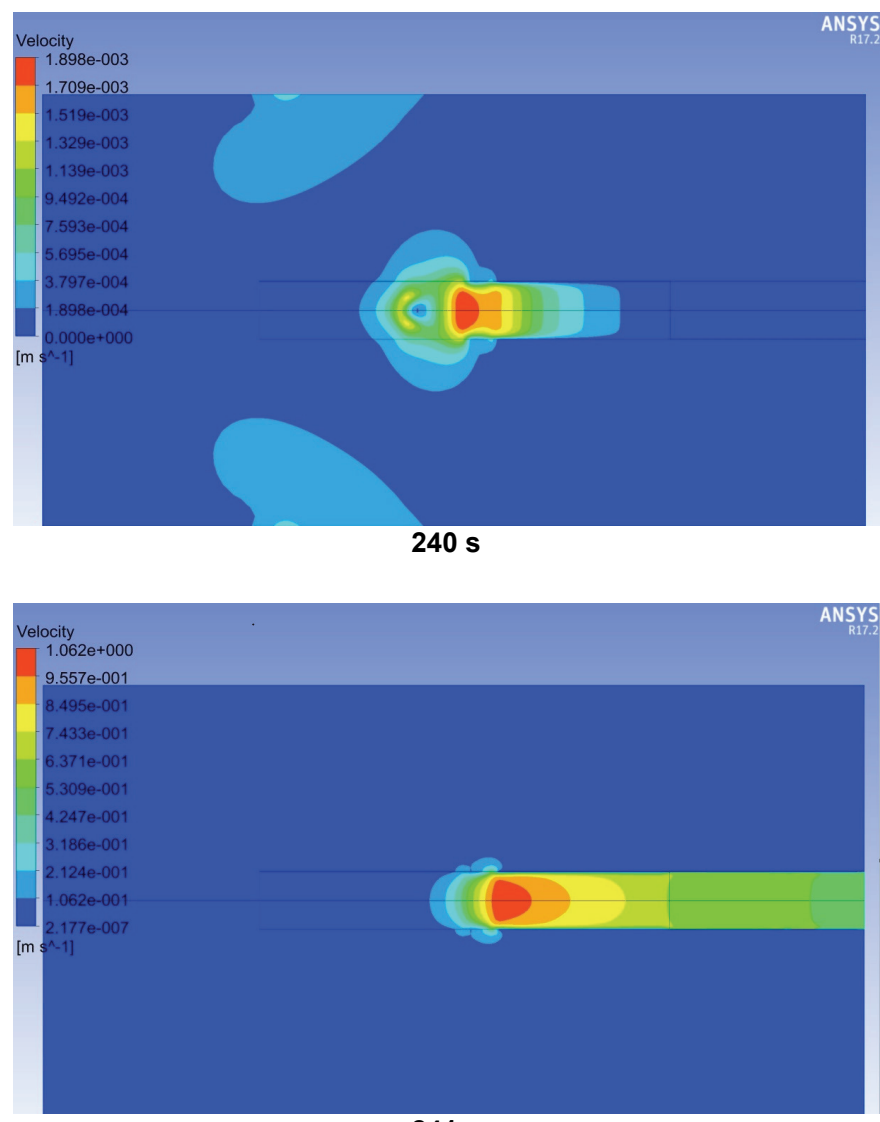

$241 s$

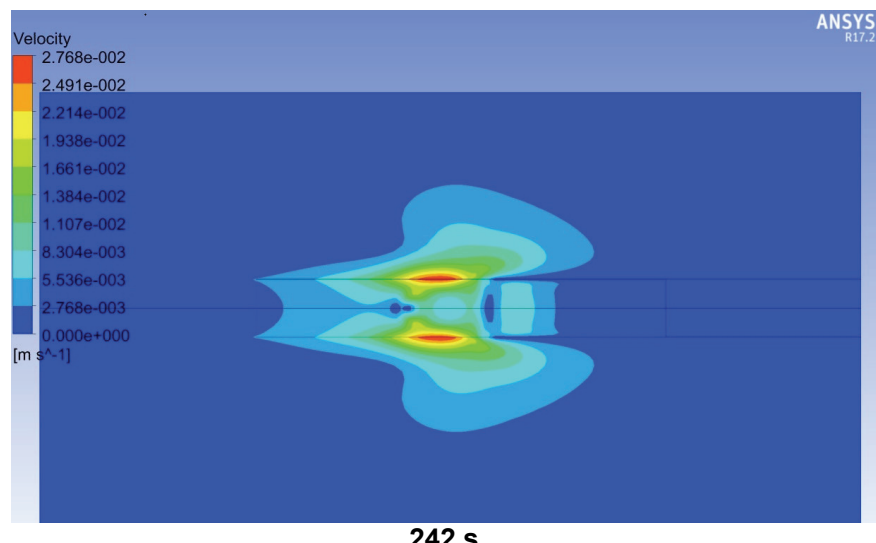

$242 s$

Figure 14. Flow velocity fields of cigarette during puffing (case 3 ). 


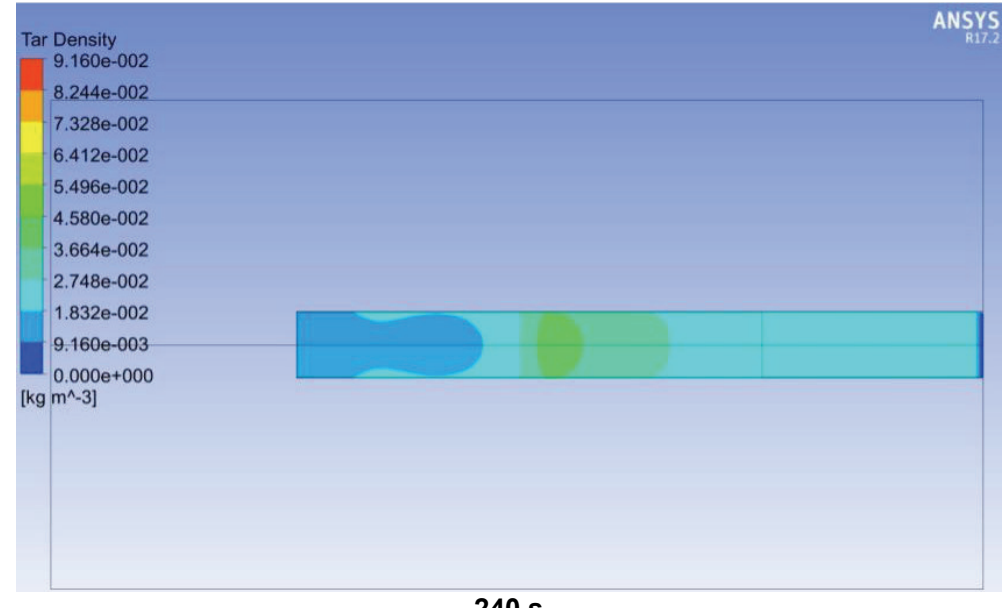

$240 \mathrm{~s}$

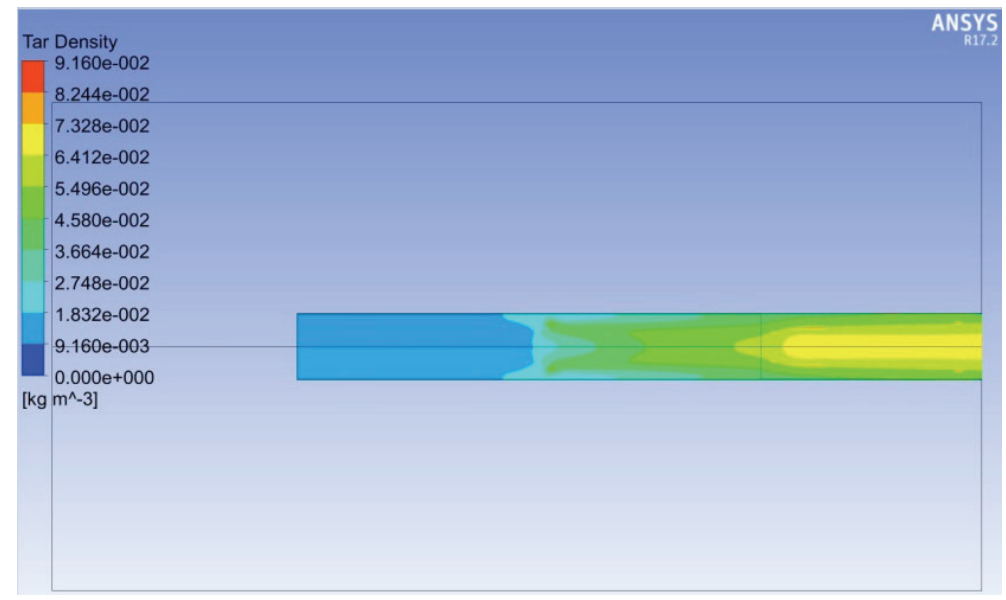

$241 s$

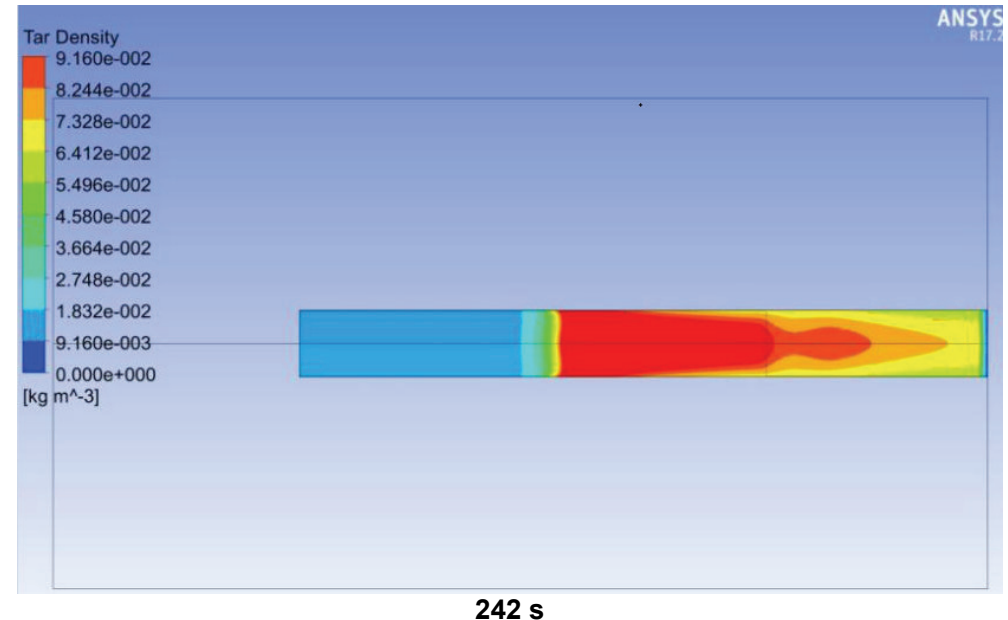

$242 \mathrm{~s}$

Figure 15. "Tar" density fields during puffing (case 3 ). 

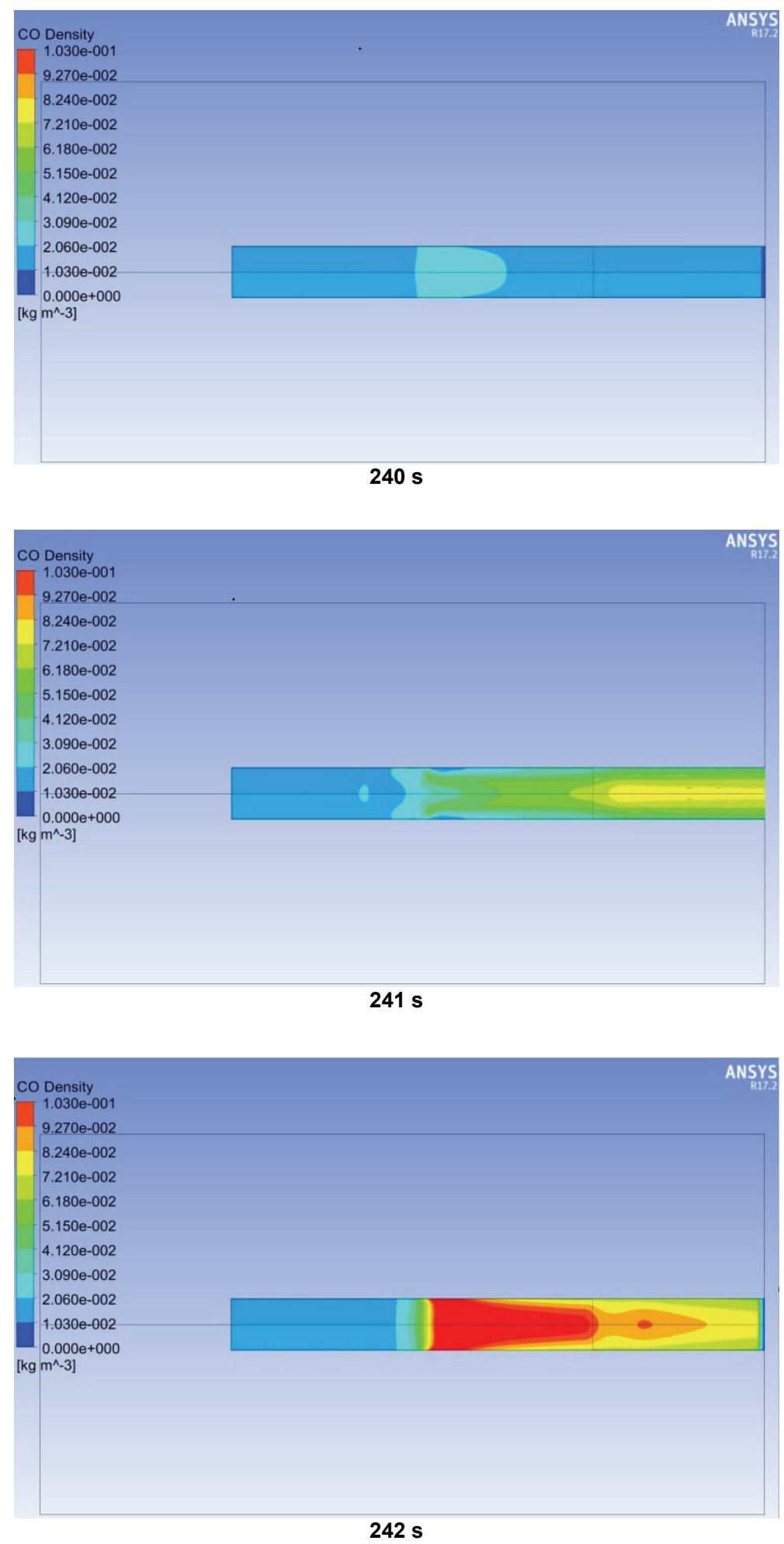

Figure 16. CO density fields during puffing (case 3 ).

\subsection{Validity of filtration efficiency}

Figure 17 shows the release amounts of "tar" at the inlet and outlet of the filter rod and the filtration efficiency during puffing (240 s $-242 \mathrm{~s})$ in case 3 . The overall filtration efficiency varied on a degree of about $44.9 \%$. There were two kinds of effects during this period. On the one hand, the flow velocity was high, which lead to a decrease in the filtration efficiency. On the other hand, the concentration of aerosol particles grew higher, which resulted in an increase in the filtration efficiency. Accordingly, these two effects tended to compensate each other and the filtration efficiency remained stable.

The total "tar" amounts released at the inlet and outlet of the filter rod were calculated to be $22.63 \mathrm{mg} / \mathrm{cig}$ and $12.19 \mathrm{mg} / \mathrm{cig}$, respectively, and the predicted filtration efficiency was $46.1 \%$. In this study, nicotine retention efficiency was chosen to represent the experimental filtration efficiency of the filter. The experimentally determined filtration efficiency for nicotine was $44.5 \%$. 


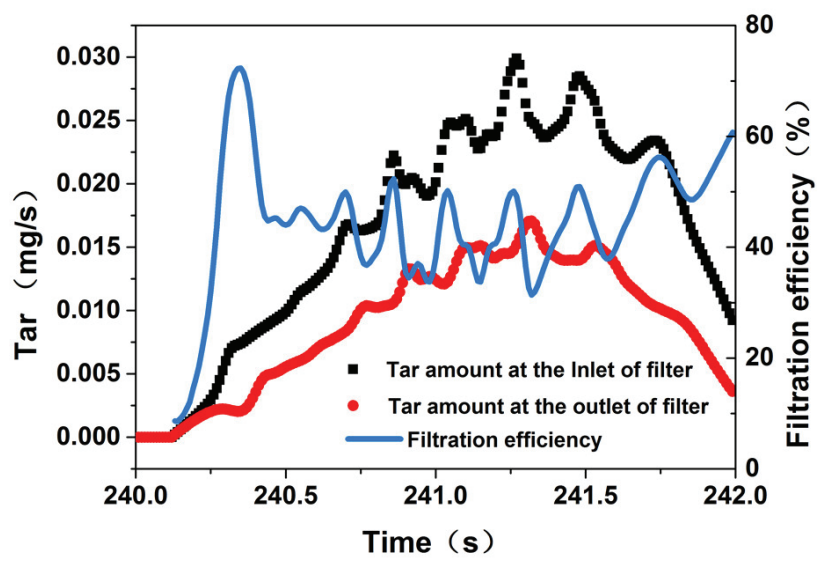

Figure 17. Released amounts of "tar" at the inlet and outlet of the filter rod and the filtration efficiency during puffing (case 3 ).

\subsection{Validity of "tar" and CO yields by changing the puff intensity}

In order to reinforce the validity and robustness of the model, case 5 was numerically simulated in which just $25 \mathrm{~mL}$ air was drawn for $2 \mathrm{~s}$, all other conditions were kept constant. In this case, the model terminated smoking at $421 \mathrm{~s}$ when the char line was at $50.0 \mathrm{~mm}$. The predicted puff number was 7.5, and the actual puff number was 7 .

Figures 18 and 19 compare the released puff-by-puff amounts of "tar" and CO in the mainstream smoke under different puff intensities. As the puff intensity decreased, "tar" and released CO amounts also decreased. The predicted yields of "tar" and CO were $9.9 \mathrm{mg} / \mathrm{cig}$ and $11.6 \mathrm{mg} / \mathrm{cig}$ in case 5 , and the experimental values were $9.3 \mathrm{mg} / \mathrm{cig}$ and $11.0 \mathrm{mg} / \mathrm{cig}$, with the relative deviations of $6.5 \%$ and $5.5 \%$, respectively. The numerical results were in good agreement with the experimental ones.

\section{CONCLUSIONS}

The cigarette burning process has been simulated using FLUENT. In contrast to previously published models, the kinetics of pyrolysis and char oxidation reactions were established at high heating rates and different oxygen concentrations and in addition, the filtration efficiency of the cigarette filter was taken into consideration. Furthermore, an experimental platform for tobacco pyrolysis and combustion reactions was designed to obtain the source terms of "tar" and $\mathrm{CO}$ at different reaction conditions, which could supply more repeatable and accurate data compared to a TG experiment. The cigarette burning properties such as the density fields, temperature field and flow velocity field were predicted by the model. The puff number, the temperatures at specific locations, the filtration efficiency and the yields of "tar" and CO under different puff intensities were calculated and compared with the experimental data, which showed a good agreement. Authors of future work in this field will be encouraged to use this model for a prediction of the cigarette burning process for different cigarette paper and filter parameters.
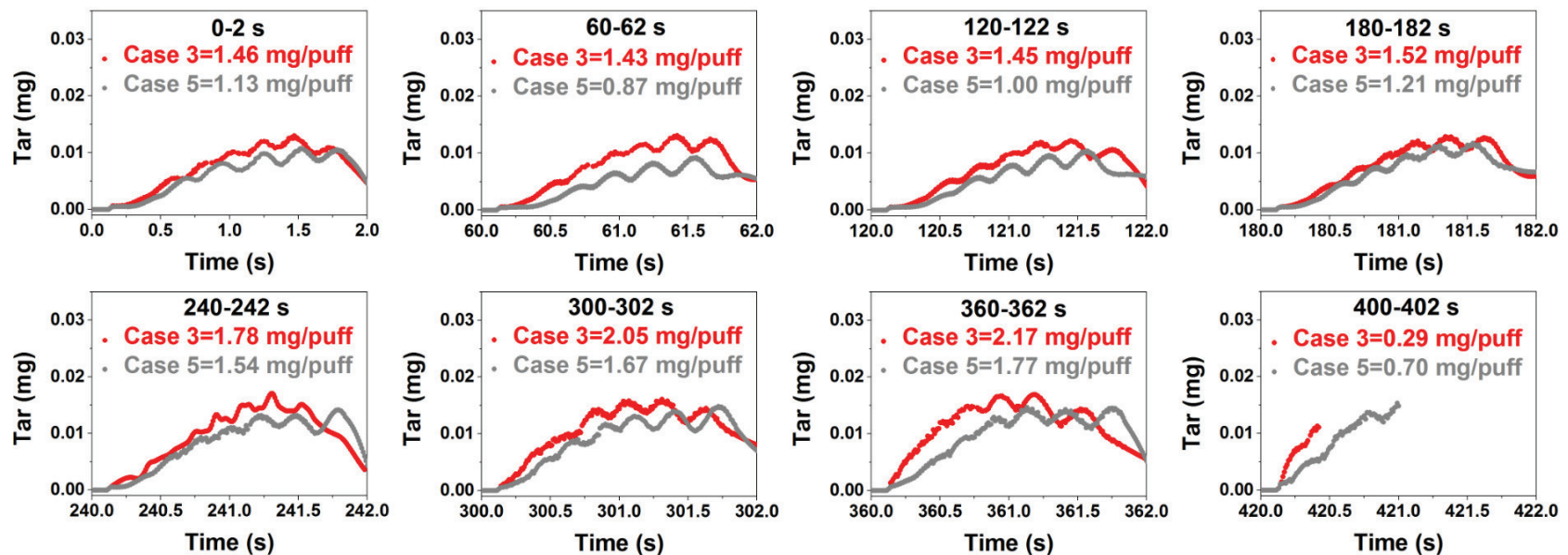

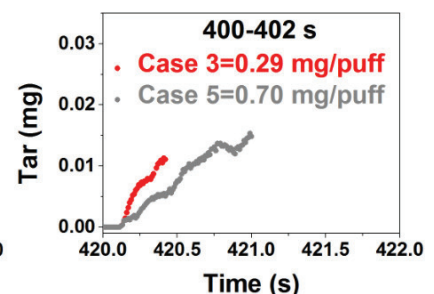

Figure 18. The puff-by-puff amounts of "tar" released in cases 3 and 5 . 

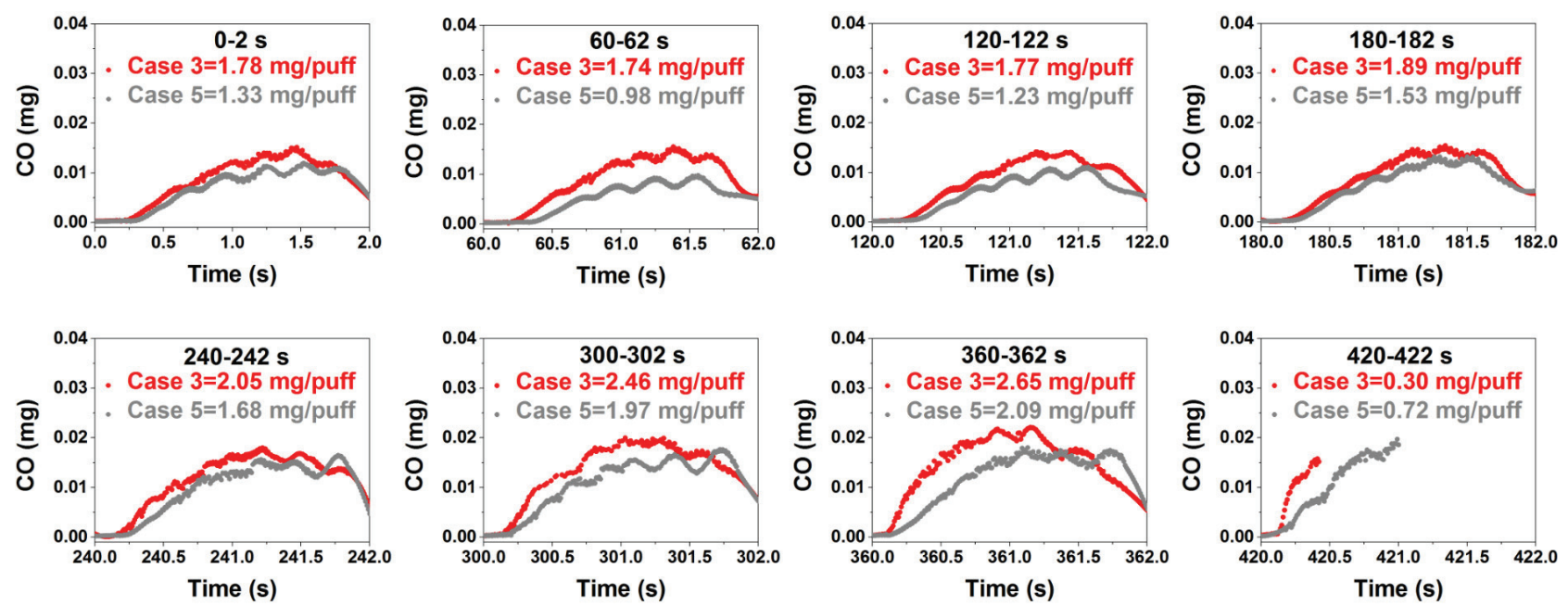

Figure 19. The puff-by-puff amounts of $\mathrm{CO}$ released in cases 3 and 5 .

\section{REFERENCES}

1. Egerton, S.A., K. Guagan, and F.J. Weinberg: The Mechanism of Smouldering in Cigarettes; Combust. Flame 7 (1963) 63-78.

DOI: $10.1016 / 0010-2180(63) 90008-7$

2. Gugan, K.: Natural Smoulder in Cigarettes; Combust. Flame 10 (1966) 161-164. DOI: $10.1016 / 0010-2180(66) 90063-0$

3. Baker, R.R.: Combustion and Thermal Decomposition Regions Inside a Burning Cigarette; Combust. Flame 30 (1977) 21-32. DOI: 10.1016/0010-2180(77)90048-7

4. Summerfield, M., T.J. Ohlemiller, and H.W. Sandusky: A Thermophysical Mathematical Model of SteadyDraw Smoking and Predictions of Overall Cigarette Behavior; Combust. Flame 33 (1978) 263-279. DOI: $10.1016 / 0010-2180(78) 90065-2$

5. Muramatsu, M., S. Umemura, and T. Okada: A Mathematical Model of Evaporation-Pyrolysis Processes Inside a Naturally Smoldering Cigarette; Combust. Flame 36 (1979) 245-262.

DOI: 10.1016/0010-2180(79)90063-4

6. Muramatsu, M., S. Umemura, and T. Okada: Studies on the Natural Smouldering of Cigarettes: III. Determination of the Thermal Properties of Tobacco Shreds Packed in Columns; Beitr. Tabakforsch. Int. 10 (1979) 17-23. DOI: 10.2478/cttr-2013-0464

7. Muramatsu, M. and S. Umemura: Kinetics of Oxidation of Tobacco Char; Beitr. Tabakforsch. Int. 11 (1981) 79-86. DOI: 10.2478/cttr-2013-0500

8. Miura, K., S. Kitao, Y. Egashira, N. Nishiyama, and K. Ueyama: Propagation of Cigarette Static Burn; Beitr. Tabakforsch. Int. 19 (2001) 277-287.

DOI: $10.2478 /$ cttr-2013-0714

9. Yi, S.-C., E.-S. Song, and M.R. Hajaligol: Mathematical Model of Smoldering Combustion in a Carbonaceous Porous Medium. Part 1. - Development of Pyrolysis and Combustion Models for a Cylindrical Geometry; J. Fire Sci. 19 (2001) 429-448.
DOI: $10.1177 / 073490401773732436$

10. Di Blasi, C.: Analysis of Convection and Secondary Reaction Effects Within Porous Solid Fuels Undergoing Pyrolysis; Combust. Sci. Technol. 90 (1993) 315-340. DOI: 10.1080/00102209308907620

11. Chen, P.: A Mathematical Model of Cigarette Smoldering Process; Beitr. Tabakforsch. Int. 20 (2002) 265-271. DOI: $10.2478 /$ cttr-2013-0740

12. Rostami, A., J. Murthy, and M. Hajaligol: Modeling of a Smoldering Cigarette; J. Anal. Appl. Pyrol. 66 (2003) 281-301. DOI: 10.1016/S0165-2370(02)00117-1

13. Rostami, A., J. Murthy, and M. Hajaligol: Modeling of Smoldering Process in a Porous Biomass Fuel Rod; Fuel 83 (2004) 1527-1536.

DOI: 10.1016/j.fuel.2003.11.018

14. Saidi, M.S., M.R. Hajaligol, and F. Rasouli: Numerical Simulation of a Burning Cigarette During Puffing; J. Anal. Appl. Pyrol. 72 (2004) 141-152.

DOI: 10.1016/j.jaap.2004.03.011

15. Wójtowicz, M.A., R. Bassilakis, W.W. Smith, Y. Chen, and R.M. Carangelo: Modeling the Evolution of Volatile Species During Tobacco Pyrolysis; J. Anal. Appl. Pyrol. 66 (2003) 235-261.

DOI: 10.1016/S0165-2370(02)00116-X

16. Eitzinger, B. and S. Pirker: Numerical Simulation of a Cigarette During Smoking; Beitr. Tabakforsch. Int. 21 (2005) 402-416. DOI: 10.2478/cttr-2013-0806

17. Saidi, M.S., M.R. Hajaligol, A. Mhaisekar, and M. Subbiah: A 3D Modeling of Static and Forward Smoldering Combustion in a Packed Bed of Materials; Appl. Math. Model. 31 (2007) 1970-1996. DOI: 10.1016/j.apm.2006.08.003.

18. Saidi, M.S., A. Mhaisekar, M.R. Hajaligol, and M. Subbiah: Mathematical Modeling of a Lit-End Cigarette: Puffing Cycle and Effects of Puff Counts; Beitr. Tabakforsch. Int. 23 (2008) 46-62.

DOI: $10.2478 /$ cttr-2013-0847

19. Du, W., J. Wen, B. Peng, X. Zhang, F. Xie, H. Liu, and K. Zhong: An Improved Theoretical Model of Ciga- 
rette Smoke Filtration Across Mono-Segment Cellulose Acetate Filters; Beitr. Tabakforsch. Int. 26 (2015) 232-240. DOI: $10.1515 / \mathrm{cttr}-2015-0011$

20. Liao, J.J., Q.L. Li, X. Deng, Z. Hu, X. Chen, Y. Li, and G.Q. Chen: Effects of Heating Rate on Fast Pyrolysis of Cut Filler of Cigarette; Tob. Sci. Technol. 49 (2016) 44-50. DOI: 10.16135/j.issn1002-0861.2016.0052

21. Cardoso, C.R., M.R. Miranda, K.G. Santos, and C.H. Ataíde: Determination of Kinetic Parameters and Analytical Pyrolysis of Tobacco Waste and Sorghum Bagasse; J. Anal. Appl. Pyrol. 92 (2011) 392-400. DOI: 10.1016/j.jaap.2011.07.013

22. Hu, S., A. Jess, and M. Xu: Kinetic Study of Chinese Biomass Slow Pyrolysis: Comparison of Different Kinetic Models; Fuel 86 (2007) 2778-2788.

DOI: 10.1016/j.fuel.2007.02.031

23. Lee, K.W. and B.Y.H. Liu: On the Minimum Efficiency and the Most Penetrating Particle Size for Fibrous Filters; Air Pollut. Control Assoc. (2012) 37-41. DOI: 10.1080/00022470.1980.10464592

24. v. Doormal, J.P. and G.D. Raithby: Enhancements of the SIMPLE Method for Predicting Incompressible Fluid Flow; Numer. Heat Transf. 7 (1984) 147-163. DOI: 10.1080/01495728408961817

25. Baker, R.R.: Product Formation Mechanisms Inside a Burning Cigarette; PECS 7 (1981) 135-153.

DOI: 10.1016/0360-1285(81)90008-3

26. Li, Q.L., G.Q. Zhang, and C.Z. Huang: Study on the Quality Consistency of Cigarette Paper Based on TGA Technology; Tob. Sci. Technol. 52 (2019) 85-93. DOI: $10.16135 /$ j.issn1002-0861.2018.0185

27. Li, B., L.C. Zhao, L. Wang, C. Liu, K.G. McAdam, and B. Wang: Gas-Phase Pressure and Flow Velocity Fields Inside a Burning Cigarette During a Puff; Thermochim. Acta 623 (2016) 22-28.

DOI: $10.1016 /$ j.tca.2015.11.006

28. ANSYS FLUENT, Fluid Simulation Software; 14.0 Users Guide, 2011. Available at: https://www.pdfdrive.com/ ansys-fluent-140-users-guide-e 188401578 .html (accessed December 2010)

Corresponding authors:

Hongxiang Zhong, M.D.

Technology Center, China Tobacco Fujian Industrial Co., Ltd. Xiamen 361021, Fujian

P.R. China

E-mail: zhx10411@fjtic.cn

Xiao Dong Chen, Ph.D.

School of Chemical and Environmental Engineering

College of Chemistry, Chemical Engineering and

Materials Science

Soochow University

Suzhou, 215123, Jiangsu

P.R. China

E-Mail:xdchen@mail.suda.edu.cn 